BRITTLE FAILURE OF A LARGE, HIGHPRESSURE ISOSTAT AND A COMPARISON ANALYSIS OF ITS TWIN VESSEL

H. A. Pohto

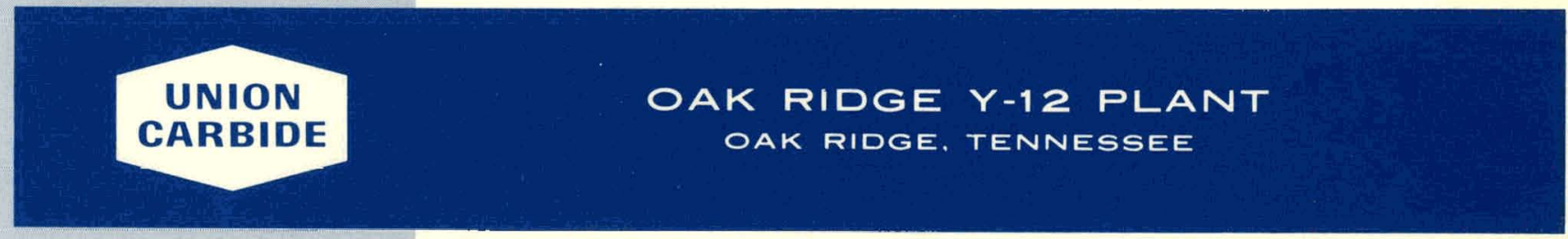

prepared for the U.S. ENERGY RESEARCH AND DEVELOPMENT ADMINISTRATION under U.S. GOVERNMENT Contract W-7405 eng 26

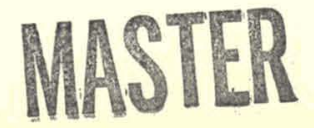




\section{DISCLAIMER}

This report was prepared as an account of work sponsored by an agency of the United States Government. Neither the United States Government nor any agency Thereof, nor any of their employees, makes any warranty, express or implied, or assumes any legal liability or responsibility for the accuracy, completeness, or usefulness of any information, apparatus, product, or process disclosed, or represents that its use would not infringe privately owned rights. Reference herein to any specific commercial product, process, or service by trade name, trademark, manufacturer, or otherwise does not necessarily constitute or imply its endorsement, recommendation, or favoring by the United States Government or any agency thereof. The views and opinions of authors expressed herein do not necessarily state or reflect those of the United States Government or any agency thereof. 


\section{DISCLAIMER}

Portions of this document may be illegible in electronic image products. Images are produced from the best available original document. 
Printed in the United States of America. Available from National Technical Information Service

U.S. Department of Commerce

5285 Port Roval Road, Springfield, Virginia 22161

Price: Prithted Copy $\$ 4.00$; Microfiche $\$ 2.25$

This report was prepared as an account of work sponsored by the United States Government. Neither the United States nor the Energy Research and Development Administration, nor any of their employees, nor any of their contractors, subcontractors, or their employees, makes any warranty, express or implied, or assumes any legal liability or responsibility for the accuracy, completeness or usefulness of any information, apparatus, product or process disclosed, or represents that its use would not infringe privately owned rights. 
Date of Issue: August 20, 1975

Report Number: Y-1989

Distribution Category: UC-38

\title{
BRITTLE FAILURE OF A LARGE, HIGH-PRESSURE ISOSTAT AND A COMPARISON ANALYSIS OF ITS TWIN VESSEL
}

\author{
H. A. Pohto \\ Engineering Senior Staff \\ Y-12 Engineering Division
}

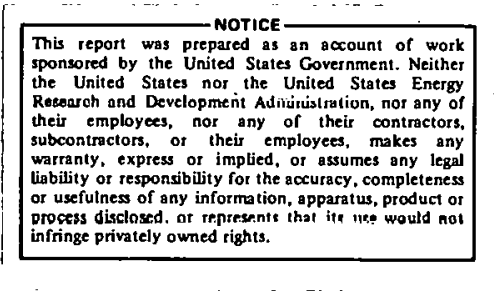

Oak Ridge Y-12 Plant

P. O. Box Y, Oak Ridge, Tennessee 37830

Prepared for the US Energy Research and Development Administration

Under US Government Contract W-7405-eng-26 

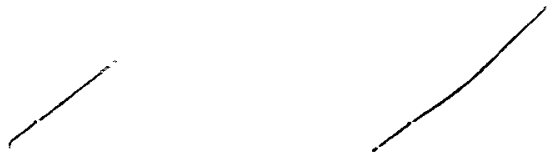

Strain-gage data from the closure thread roots of a large, high-pressure isostat, obtained over a time interval of several years, compared remarkably well with the calculated results. Similar post-failure calculations of a pressure vessel that ruptured under pressure, operating at the original conditions, showed that failure was imminent and predictable. 


\section{CONTENTS}

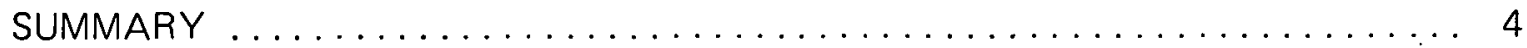

INTRODUCTION $\ldots \ldots \ldots \ldots \ldots \ldots \ldots \ldots \ldots \ldots \ldots \ldots \ldots \ldots \ldots \ldots$

ANALYSES OF THE TWO HIGH-PRESSURE ISOSTATS . . . . . . . . . . . 10

Ruptured Vessel . . . . . . . . . . . . . . . . . . . . . . . 10

Stress Analysis of the Thread Roots and Fatigue Life $\ldots \ldots \ldots \ldots \ldots \ldots \ldots$

Post Failure Fracture Mechanics Analysis . . . . . . . . . . . . . . . . 11

Twin Vessel . . . . . . . . . . . . . . . . . . . . . . . . . . . . . 16

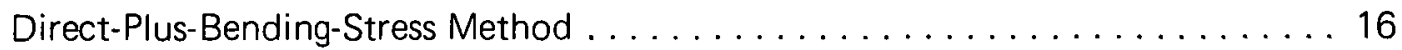

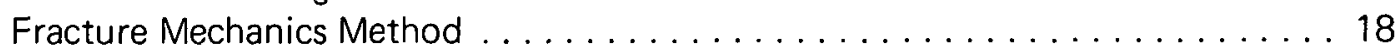

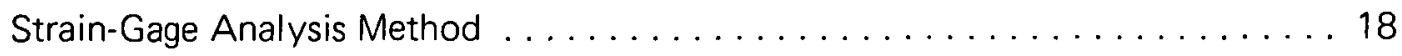

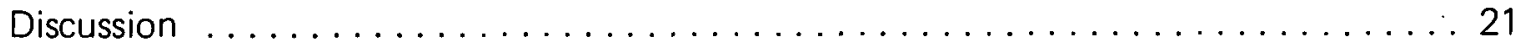

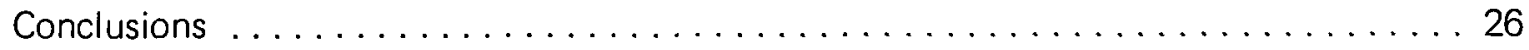

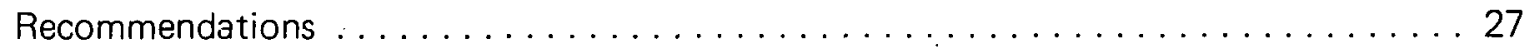

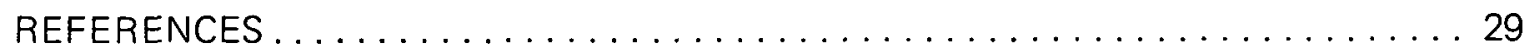

ACKNOWLEDGEMENTS $\ldots \ldots \ldots \ldots \ldots \ldots \ldots \ldots \ldots \ldots \ldots \ldots \ldots \ldots$

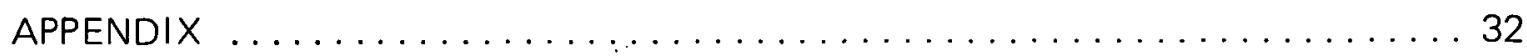

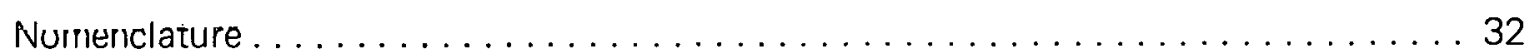




\section{SUMMARY}

Twin isostats [30 inches $(0.762 \mathrm{~m})$ ID by 120 inches $(3.048 \mathrm{~m})$ deep], designed for an operating pressure of 30,000 psi (207 MPa), have been in use at the Oak Ridge $Y-12$ Plant. (a) Just prior to placing the second vessel in operation, the first isostat failed catastrophically at the closure thread root.

Strain-gage data from the closure thread roots of the second vessel, obtained over a time interval of several years, compared remarkably well with the calculated results. Similar post-failure calculations of the ruptured isostat, operating at the original conditions, showed that failure was imminent and predictable.

(a) Operated by the Union Carbide Corporation's Nuclear Division for the US Energy Research and Development Administration. 


\section{INTRODUCTION}

Two 30-inch (0.762-m)-ID by 120-inch (3.048-m)-deep isostats, designed for a 30,000-psi (207-MPa) operating pressure, using mineral oil at ambient temperatures as the pressing medium, were installed for operation at the Oak Ridge Y-12 Plant.

The first pressure vessel, while in operation, ruptured abruptly during its 1554th cycle at an operating pressure of 28,500 psi (194 MPa).(1) The failure occurred at the lower closure in the root of the first thread. The second vessel, its near "twin", was being installed at the time of the rupture of the first isostat. Figures 1 through 5 present views of the ruptured vessel and of the second vessel.

These vessels are of multiwall, threaded-closure construction. The upper closures are breech-type assemblies with an interrupted buttress thread; the lower closures have a continuous buttress thread (see Figures 2 and 5).

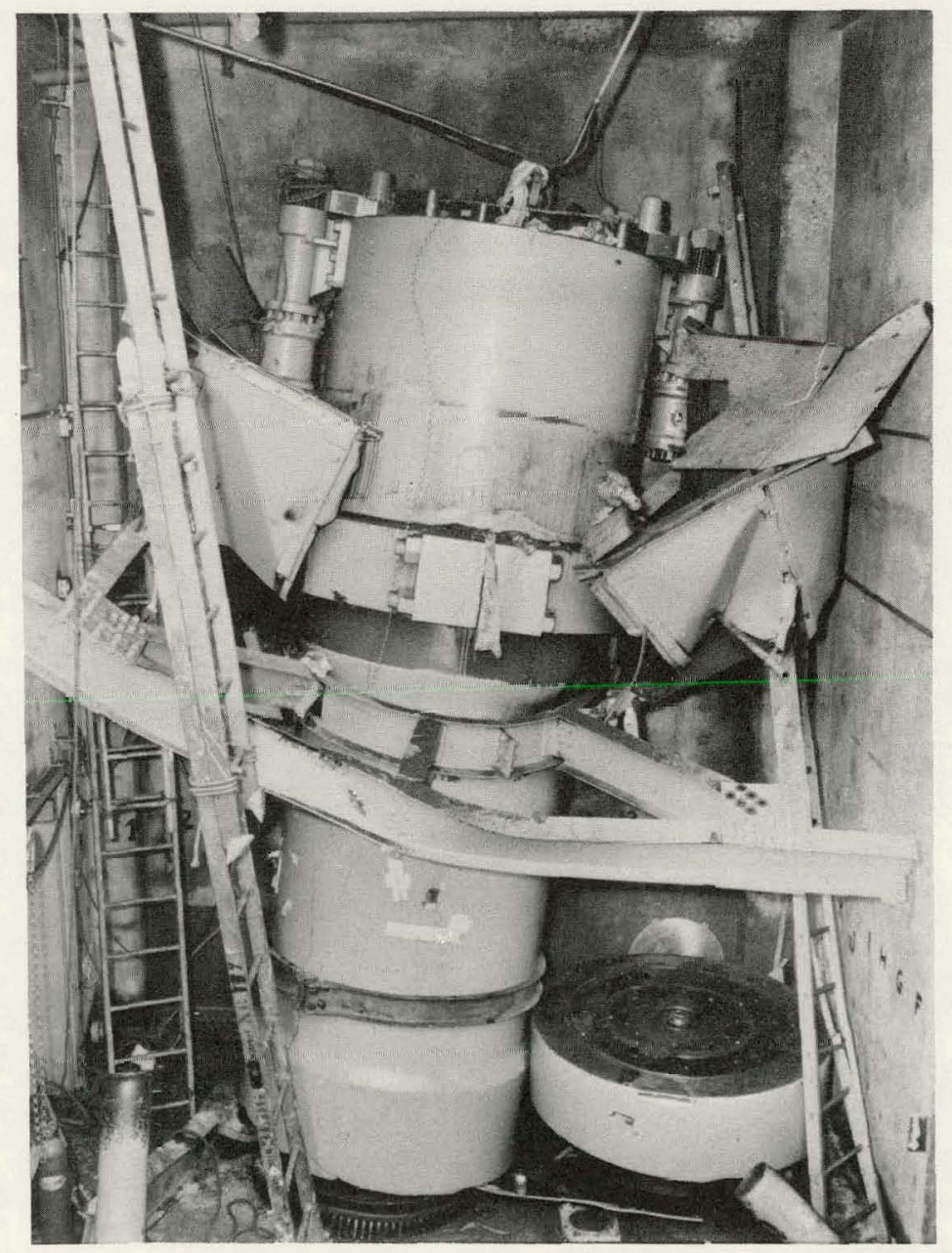

137819

Figure 1. THE FAILED PRESSURE VESSEL SHOWING DAMAGE TO THE VESSEL AND TO ITS CONTAINMENT CELL AREA. 


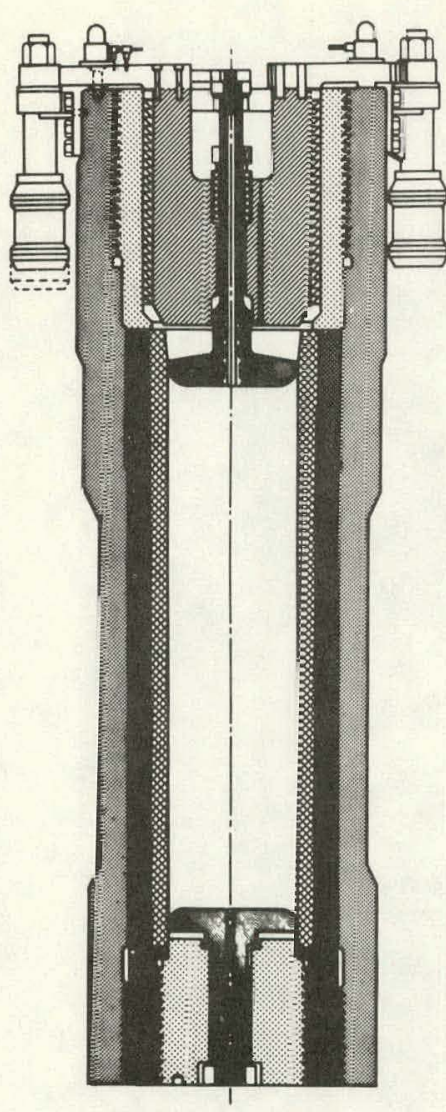

(a) Original (ruptured) Vessel.

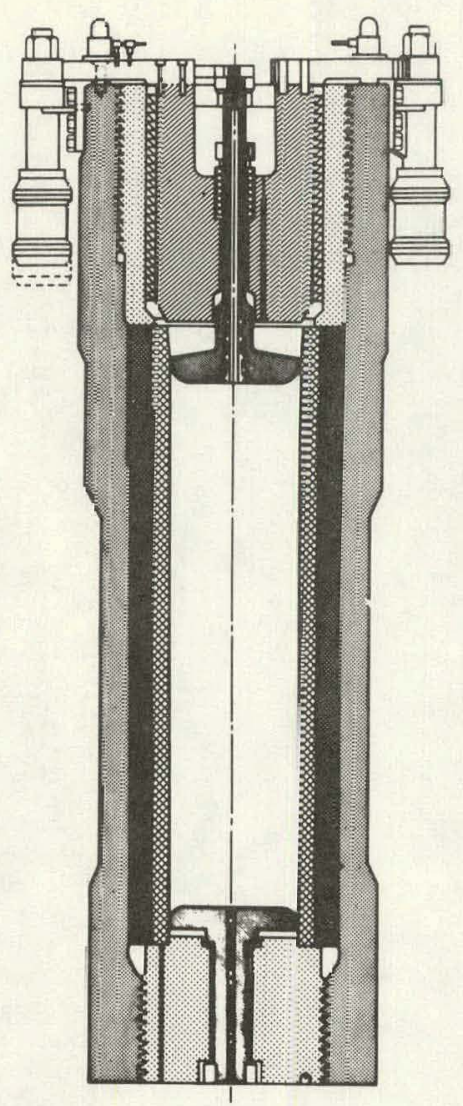

(b) "Tnin" (autoclave) Vessel.

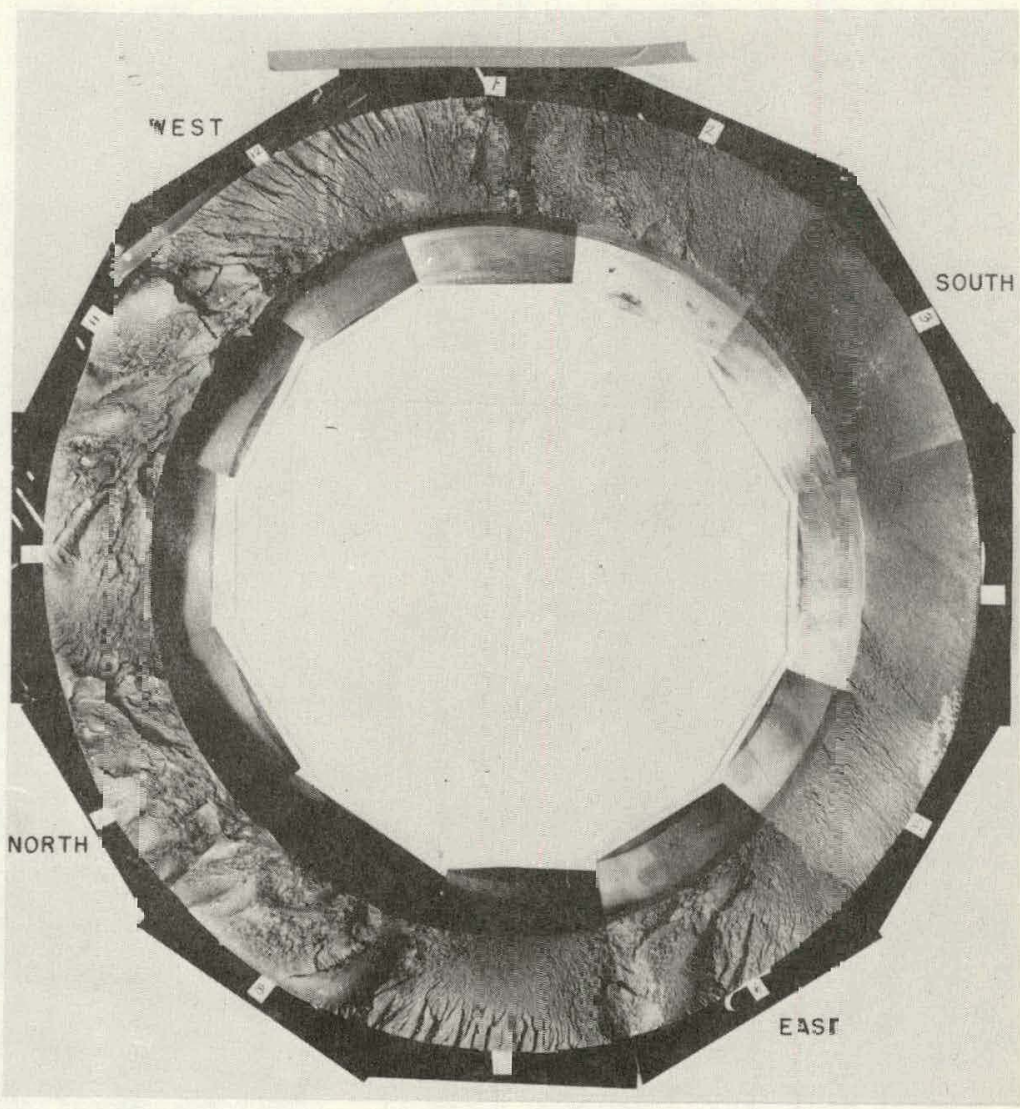

137817

Figure 3. FRACTURE FACE OF THE RUP-URED VESSEL (Top Section)

Figure 2. COMPARISON OF THE TWO PRESSUFE VESSELS. (Chamber Dimer sions: $30^{\prime \prime}$ ID x $120^{\prime \prime}$ Deep: 


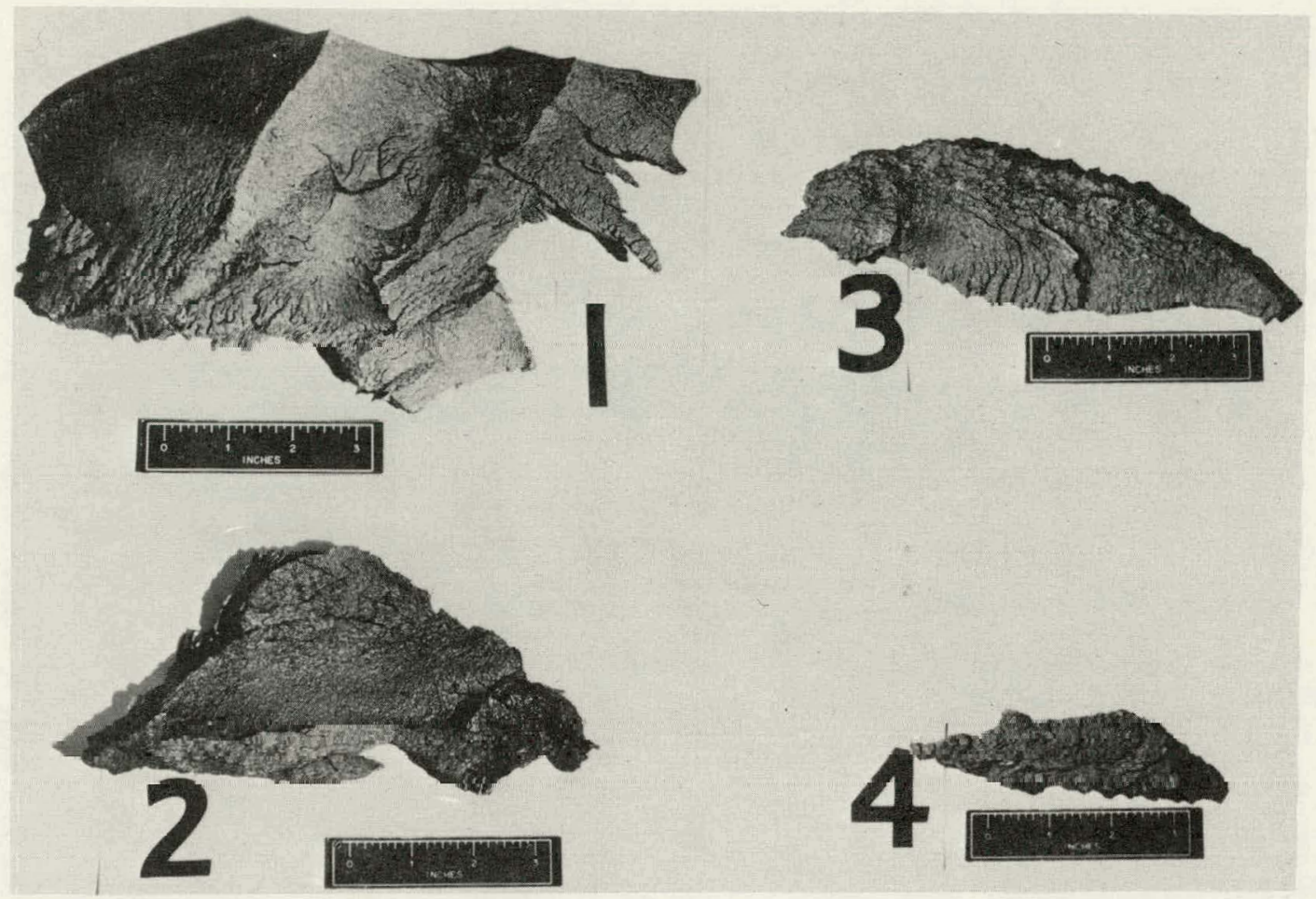

Figure 4. FRAGMENTS FROM THE RUPTURED AREA.

137820

Apparently no stress analysis of the threaded area had been made prior to the failure. A post-failure analysis of the stresses in the root of the thread of the ruptured vessel and its comparison to calculated and verified strain-gage data from the "twin" vessel revealed that failure could have been predicted at the designed operating pressure. Strain-gage data and other methods of fatigue-life calculation verified these findings.

The "twin" vessel was subsequently modified to a gas autoclave, (2) installed with a water-cooled liner and electrical feed throughs in the lower closure, and operated at one half the original design pressure (note Figures 6 and 7 ). Both vessels were constructed from nickel steel forgings. Table 1 lists some physical and chemical properties of the steel structural material of the two isostats.

After several years of operating the "twin" vessel as an argon gas autoclave, another detailed inspection and an analysis of this surviving vessel was made. This analysis is the principal subject of this report.
Table 1

PHYSICAL AND CHEMICAL PROPERTIES OF THE STEEL FORGINGS FOR THE TWO ISOSTATS

\begin{tabular}{lcc}
\hline & Ruptured Vessel & Twin Vessel \\
\hline Yield Strength (psi/MPa) & $97,500 / 672$ & $93,000 / 641.2$ \\
Tensile Strength (psi/MPa) & $117,500 / 810$ & $114,000 / 786$ \\
Elongation (\%) & 15.5 & 17 \\
Chemical Composition (\%) & & \\
$\quad$ Carbon & 0.28 & 0.29 \\
Manganese & 0.70 & 0.73 \\
Phosphorus & 0.015 & 0.009 \\
Sulfur & 0.011 & 0.013 \\
Silicon & 0.19 & 0.19 \\
Nickel & 2.64 & 2.73 \\
Chromium & 0.25 & 0.11 \\
Vanadium & 0.07 & 0.08 \\
Molybdenum & 0.48 & 0.48 \\
\hline
\end{tabular}




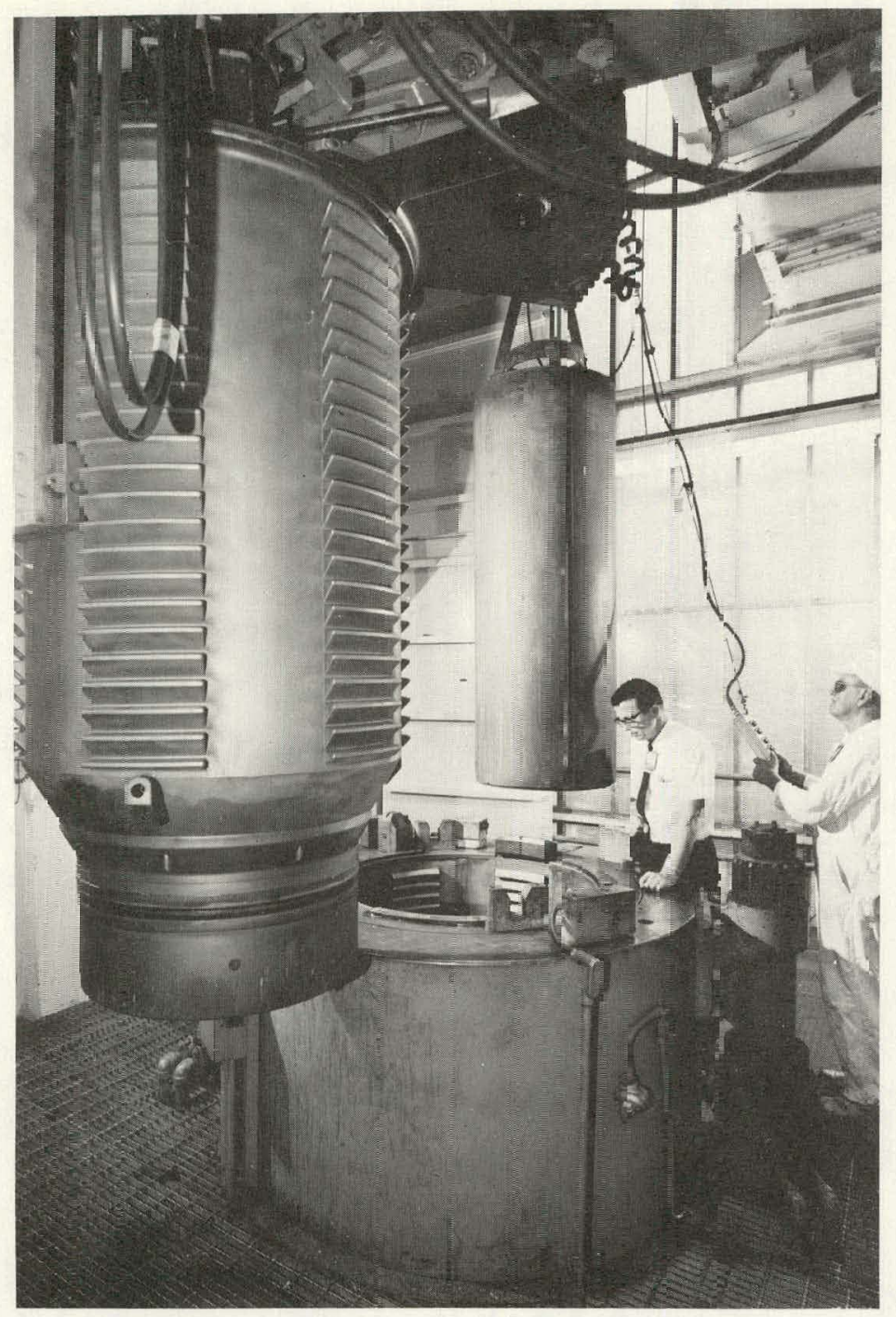

Figure 5. UPPER CLOSUFE OF THE TW N VESSEL.

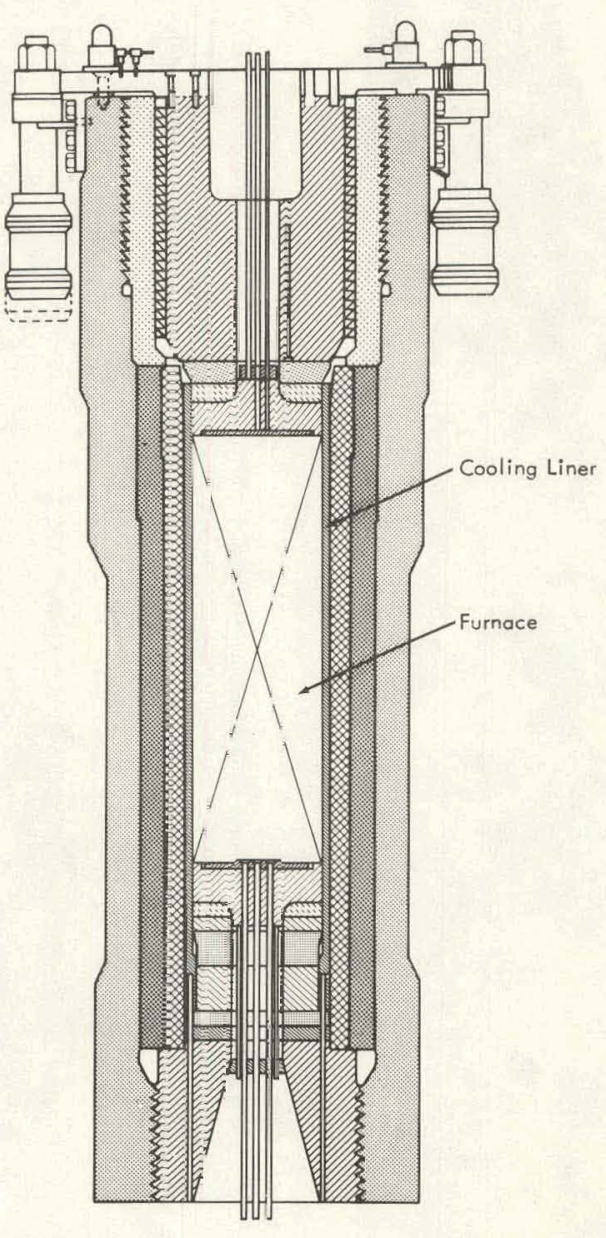

Figure 6. MODIF CATION OF THE TWIN VESSEL TO OPERATE AS A GAS AUTDCLAVE. 


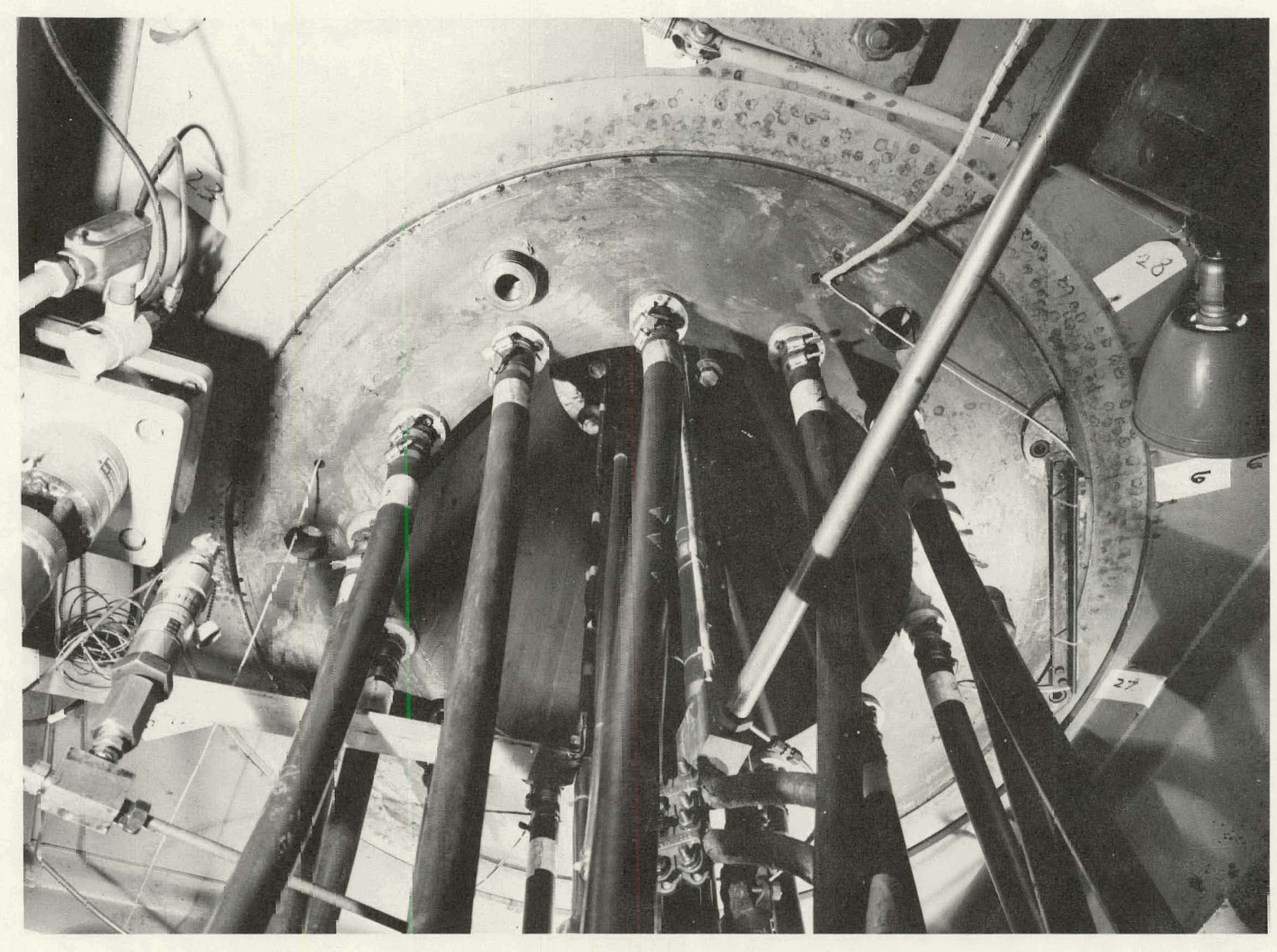

Figure 7. BOTTOM FEED THROUGHS FOR THE TWIN VESSEL. 


\section{ANALYSES OF THE TWO HIGH-PRESSURE ISOSTATS}

\section{RUPTURED VESSEL}

\section{Stress Analysis of the Thread Roots and Fatigue Life}

Direct-Plus-Bending-Stress Method - In the shell of the ruptured vessel, the tensile stress at the lower first thread may be determined by the direct-plus-bending-stress method, therefore:(3)

$$
\begin{gathered}
\text { Tensile Stress }=\sigma_{z}=\frac{P}{\Lambda}+\frac{M y_{1}}{1}, \text { or } \\
\sigma_{z}=\frac{P}{A}\left(1+\frac{K_{m} w y_{1}}{r^{2}}\right),
\end{gathered}
$$

where (note Figure 8): (b)

$$
\begin{aligned}
& \mathrm{P}=137,000 \mathrm{lbs} / \text { linear inch }(62,143 \mathrm{~kg} / \mathrm{cm}) \text { of circumference at the pitch line; } \\
& \text { A }=9.337 \mathrm{in}^{2}\left(60.22 \mathrm{~cm}^{2}\right) \text {; } \\
& w=4.695 \text { in }(11.91 \mathrm{~cm}) \text {; } \\
& K_{m}=0.505 \text {, using Timeshenko; }{ }^{(4)} \\
& \mathrm{y}_{1}=4.125 \mathrm{in}(10.46 \mathrm{~cm}) \text {; } \\
& \mathrm{r}^{2}=5.15 \mathrm{in}^{2}\left(33.22 \mathrm{~cm}^{2}\right) \text {; } \\
& \text { b }=15.00 \text { in }(38.1 \mathrm{~cm}) \text {; } \\
& \text { c } \quad=0.994 \text { in }(2.52 \mathrm{~cm}) \text {, depth of the thread; } \\
& \mathrm{R}=24.55 \mathrm{in}(62.36 \mathrm{~cm}) \text {, pitch radius of the thread; } \\
& \mu \quad-0.3 \text { (Puissuri's raliu), required for } \mathrm{K} \cdot \mathrm{m} \text { determination; } \\
& k=3.5, \text { the stress concentration factor; }(5) \\
& \mathrm{t}=8.475 \text { in }(21.52 \mathrm{~cm}) \text {, the wall thickness from the pitch line to the outside }
\end{aligned}
$$

(b) A nomenclature of all terms is contained in the Appendix. 


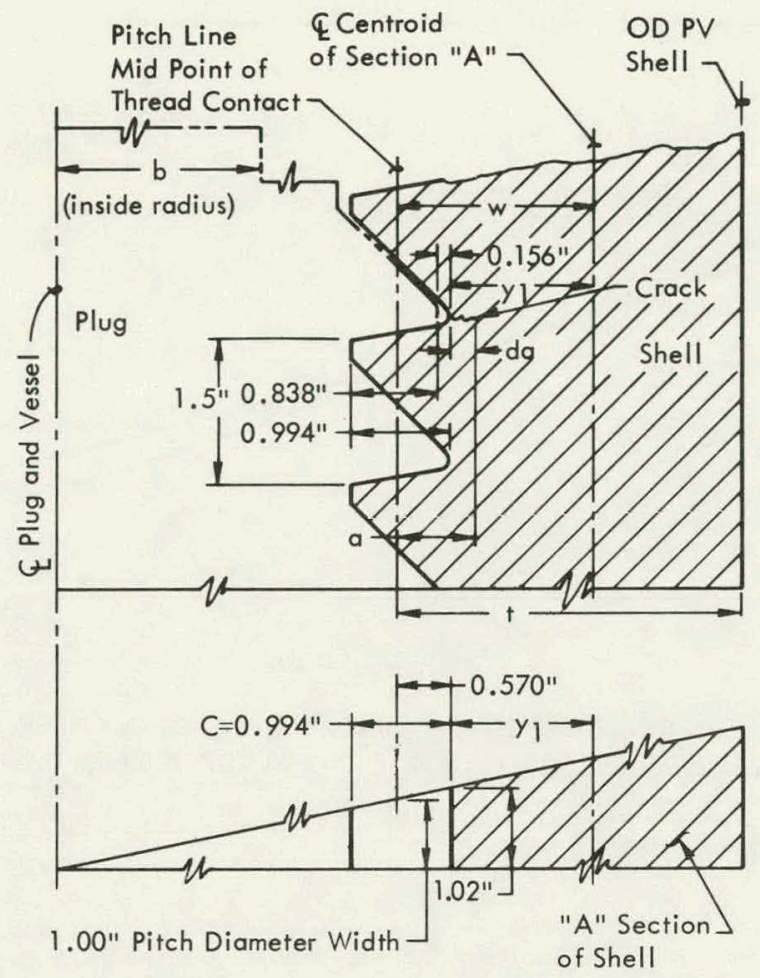

Figure 8. DIMENSIONAL DEFINITION OF TERMS.

(See Equation 1)

Therefore, the total stress, $\sigma_{\mathrm{Z}}$ at the first thread root is:

$$
\sigma_{z}=\frac{P}{A}\left(1+\frac{K_{m} w_{1}}{r^{2}}\right)=42,500 \text { psi (292.9 MPa) }
$$

The longitudinal alternating stress range at the first throad is:

$$
\mathrm{S}_{\mathrm{Z}}=\mathrm{k} \sigma_{\mathrm{Z}}=3.5(42,500 \mathrm{psi})=149,000 \mathrm{psi}(1027.2 \mathrm{MPa})
$$

Alternating stress component is: (6)

$$
S_{a}=\frac{S_{z}}{2}=14,500 \text { psi (513.6 MPa) }
$$

Life at a 30,000 -psi (207-MPa) operating pressure is estimated at 1300 cycles ${ }^{(6)}$ (see Figure 9).

\section{Post Failure Fracture Mechanics Analysis}

Utilizing the Wcssel and Mayer (7) tension and bending equations for determining the critical stress intensity factor, the following is obtained: 


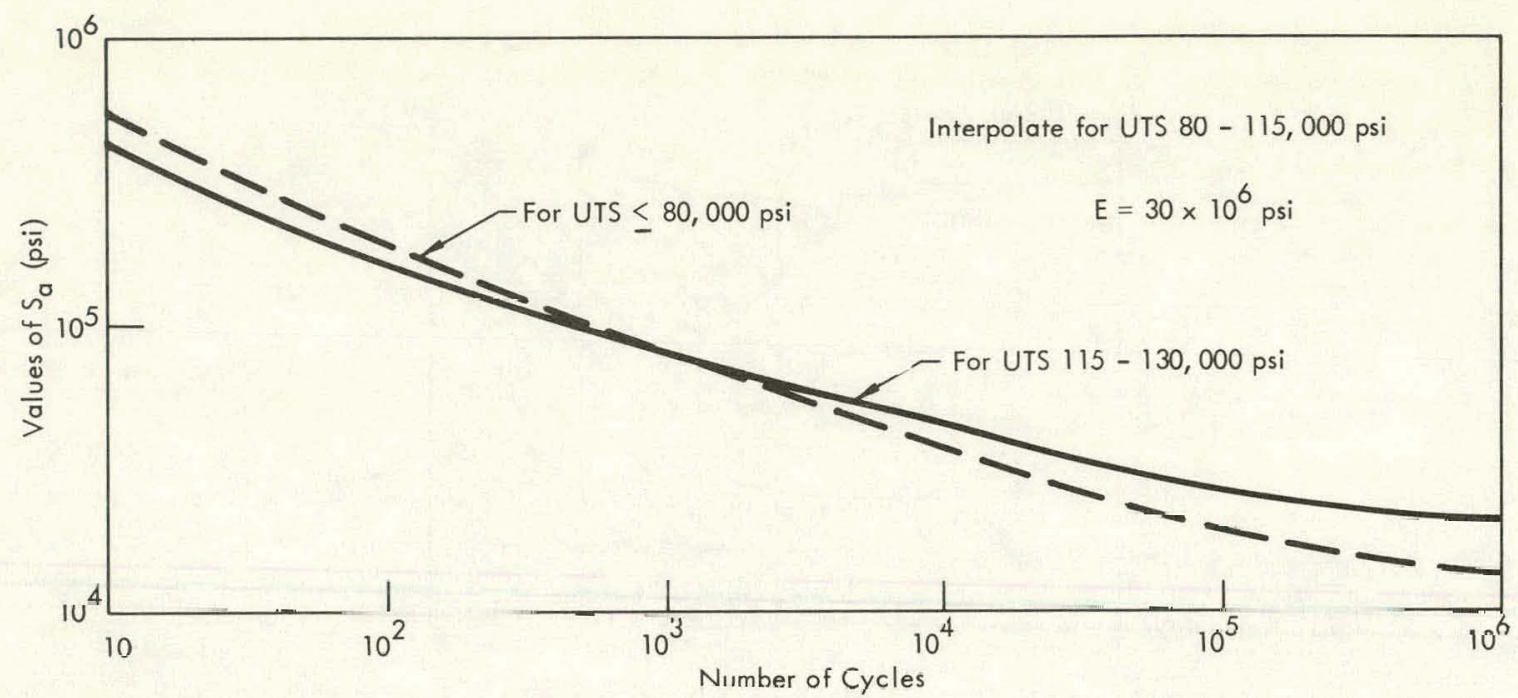

Figure 9. DESIGN FATIGUE CURVES FOR CARBON, LOW-ALLOY, SERIES 4XX STEELS; HIGH-ALLOY STEELS, AND HIGH-TENSILE STEELS FOR TEMPERATURES NOT TO EXCEED $700^{\circ} \mathrm{F}$. (Taken from ASME Section VIII, Division 2, Figure 5-110.1(6))

$$
K_{1}=\sigma_{0} \sqrt{\pi a} k\left(\frac{a}{t}\right)+\frac{6 M}{(t-a)^{3 / 2}} h\left(\frac{a}{t}\right),
$$

where:

$$
\begin{aligned}
& t \quad=8.475 \mathrm{in}(21.52 \mathrm{~cm}) \\
& \sigma_{O}=\frac{P}{A}=14,672 \mathrm{psi}(101 \mathrm{MPa}) \\
& M=K_{m} P_{W}=324,477 \mathrm{in} \mathrm{Ibs}(36,660 \mathrm{~N} \cdot \mathrm{m}) \\
& k\left(\frac{a}{t}\right) \text { and } \mathrm{h}\left(\frac{a}{t}\right) \text { are tabulated shape factors; }(8)
\end{aligned}
$$

a represents the crack length from the pitch line;

$$
\begin{aligned}
& a_{O}=0.570 \text { in }(14.48 \mathrm{~mm}) \text {, distance from the pitch line to the root of the thread; } \\
& a_{C}=0.570+0.125=0.695 \text { in }(17.6 \mathrm{~mm})
\end{aligned}
$$

The maximum generated crack at failure was $0.12 \mathrm{~b}$ in $(3.18 \mathrm{~mm})$.

The generated crack depth was scaled from an available photograph (see Figure 10). This dimension [0.125 in $(3.18 \mathrm{~mm})$ ] was used similar to data that could be obtained from laboratory tests of material specimens to determine the $\mathrm{K}_{\mathrm{I}}$. No material specimens were available at the time of this study. 


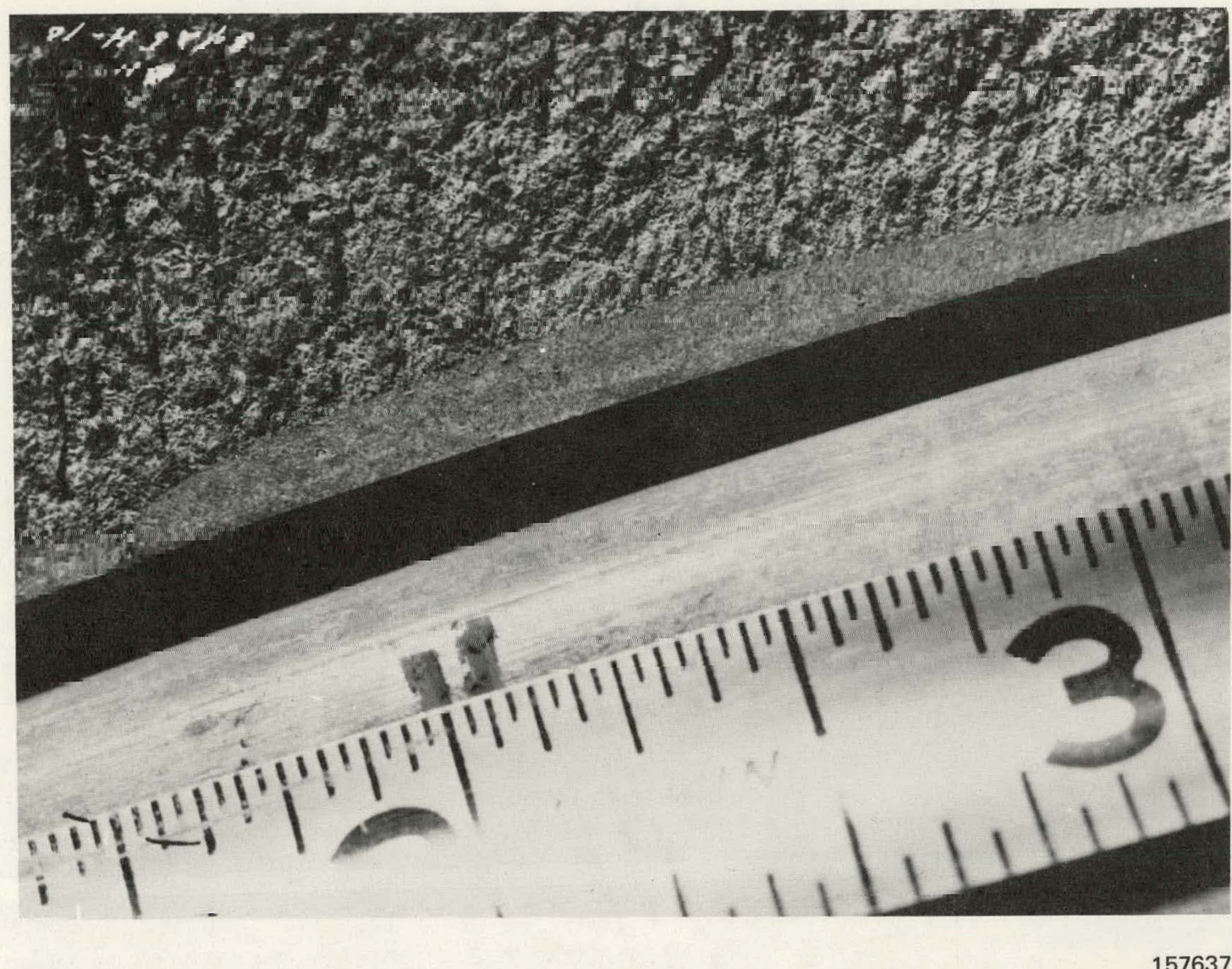

Figure 10. ACTUAL CRACK GROWTH AT THE ROOT OF THE FIRST THREAD OF THE RUPTURED VESSEL.

Thus:

$$
\begin{aligned}
& \mathrm{K}_{\mathrm{O}}=56,061 \mathrm{psi} \sqrt{\mathrm{in}}(61.55 \mathrm{MPa} \sqrt{\mathrm{m}}) \text {, and } \\
& \mathrm{K}_{\mathrm{I}_{\mathrm{C}}}=65,057 \mathrm{psi} \sqrt{\mathrm{in}}(71.5 \mathrm{MPa} \sqrt{\mathrm{m}}) .
\end{aligned}
$$

To determine the crack growth rate, the ferrite-pearlite equation derived by Barsom (8) was used (see Figure 11):

$$
\frac{d a}{d N}=3.6 \times 10^{-10}\left(\Delta K_{l}\right)^{3}
$$

where a is in inches; $\Delta K_{1}$ in $k s i \sqrt{i n}$; and $N$, the number of cycles.

The increments of increase of a (from $a_{0}$ to $a_{C}$ ) may be computed and tabulated. Since the critical da of 0.125 inch was small compared to the wall thickness, the avcrage $\frac{d a}{d N}$ was determined from the $\mathrm{K}_{\mathrm{O}}$ and $\mathrm{K}_{\mathrm{C}}$ values. 


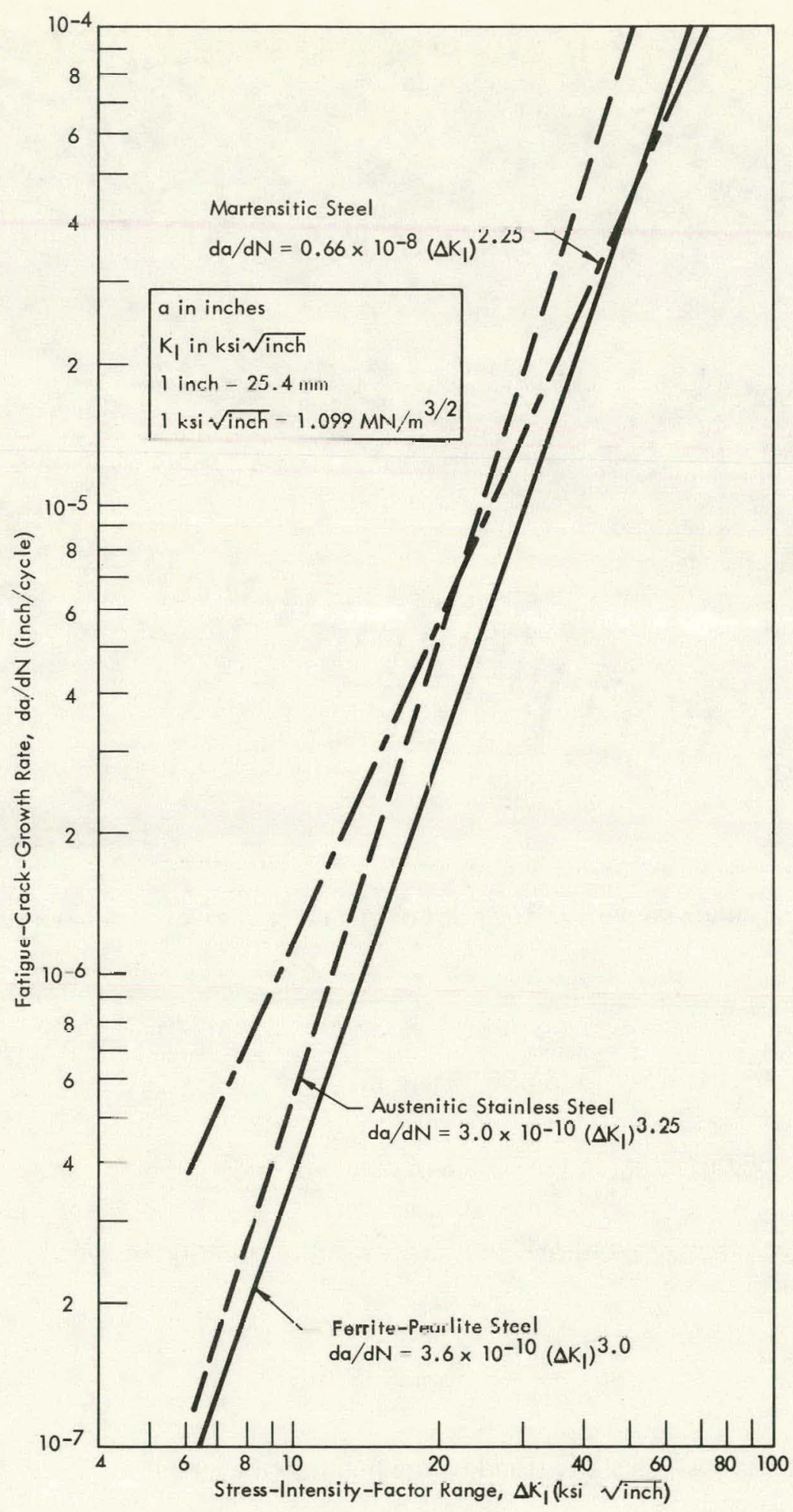

Figure 11. FATIGUE-CRACK-PROPAGATION BEHAVIOR OF VARIOUS STEELS. (From Barsom (8)) 
Thus:

$$
\frac{\mathrm{da}}{\mathrm{dN}}(\mathrm{avg})=7.995 \times 10^{-5} \text { in }(20.3 \mathrm{~nm}) / \text { cycle, }
$$

and the number of cycles $(\mathrm{N})$ to failure:

$$
N=\frac{0.125}{7.995 \times 10^{-5}}=1563 \text { cycles. }
$$

The classical equation for the stress intensity factor, $K_{1}$, was also used since the crack was small compared to the wall thickness:

$$
K_{1}=\sigma_{2} \sqrt{\pi a}
$$

where $\sigma_{Z}$, the gross stress (ie, tension plus bending) $=42,500 \mathrm{psi}(293 \mathrm{MPa})$.

In Equation 8, a ranged from 0.570 to 0.695 in $(14.48-17.6 \mathrm{~mm})$; and, using Equation 5 for $\frac{d a}{d N}$ :

$$
\text { the average } \frac{\mathrm{da}}{\mathrm{dN}}=7.864 \times 10^{-5} \text { in }(19.9 \mathrm{~nm}) / \text { cycle } \text {. }
$$

Furthermore:

$$
N=\frac{0.125}{7.864 \times 10^{-5}}=1590 \text { cycles to failure. }
$$

Merkle ${ }^{(9)}$ gives for the thick-wall vessel equation:

$$
K_{1}=(\pi a)^{1 / 2}\left[\sigma_{z} f\left(\frac{a}{t}\right)+\sigma_{O} g\left(\frac{a}{t}\right)\right] \text {. }
$$

where:

$\sigma_{\mathrm{Z}}$ represents the gross stress (tension pius bending), and

$f\left(\frac{a}{t}\right)$ and $g\left(\frac{a}{t}\right)$ are the tabulated stress factors. (9)

Thus:

$$
\begin{aligned}
& \mathrm{K}_{\mathrm{C}}=66,564 \mathrm{psi} \sqrt{\mathrm{in}}(73.1 \mathrm{MPa} \sqrt{\mathrm{m}}) \text {, and } \\
& \mathrm{N}=1362 \text { cycles to failure. }
\end{aligned}
$$


Paris and Sih, (10) for an eccentrically loaded semi-infinite crack, have derived the following equation:

$$
K_{I}=\frac{P}{(2 \pi a)^{1 / 2}}
$$

where $P$, the eccentric load $[137,000$ lbs $(609376 \mathrm{~N})]$, gives the comparable value:

$$
\mathrm{K}_{\mathrm{C}}=65,559 \mathrm{psi} \sqrt{\mathrm{in}}(72 \mathrm{MPa} \sqrt{\mathrm{m}})
$$

Corten and Sailors $(11)$ derived an empirical relationship between Charpy $\vee$-notch data, $C_{V}$, and $\mathrm{K}_{\mathrm{C}}$ in temperatures below and at the transition tempcrature lu Llık-section stex:!: iı the $C_{V}$ range of 5 to $50 \mathrm{ft} \mathrm{lbs}$. This relation is:

$$
K_{I_{C}}^{2}=8 E\left(C_{V}\right)
$$

where:

$$
\begin{aligned}
& \mathrm{K}_{\mathrm{C}} \text { represents the critical intensity factor, psi } \sqrt{\mathrm{in}} \text {, } \\
& \mathrm{C}_{V} \text { the Charpy values in } \mathrm{ft} \mathrm{Ibs} \text {, and } \\
& E \text { has a value of } 30,000,000 \mathrm{psi} \text {. }
\end{aligned}
$$

The temperature of the ruptured vessel at the time of failure was appruximately $17^{\circ} \mathrm{C}$, wcll helow the 540 C. nil-ductility temperature (NDT) value. The Charpy $V$-notch vilues at that temperature averaged $16.5 \mathrm{ft} \mathrm{lbs}$ (see Figure 12).

Thus:

$$
\begin{aligned}
& K_{T_{C}}^{2}=30 \times 10^{0}(8)(16.5), \text { and } \\
& K_{I_{C}}=62,928 \mathrm{psi} \sqrt{\mathrm{in}}(69.2 \mathrm{MPa} \sqrt{\mathrm{m}}) .
\end{aligned}
$$

This value compares favorably with the $\mathrm{K}_{\mathrm{I}_{\mathrm{C}}}$ values determined by Equation 4.

\section{TWIN VESSEL}

\section{Direct-Plus-Bending-Stress Method}

For the twin vessel, Equations 1 and $1 \mathrm{a}$ and Figure 8 have the following values:(1)

$\mathrm{P}=162,000 \mathrm{lbs} /$ linear inch $(28.9 \mathrm{~kg} / \mathrm{cm})$ of circumference (at the pitch line), at the design pressure of 30,000 psi; 


$$
\begin{aligned}
& A \quad=15.1 \mathrm{in}^{2}\left(97.4 \mathrm{~cm}^{2}\right) ; \\
& w \quad=6.83 \mathrm{in}(17.32 \mathrm{~cm}) ; \\
& K_{m}=0.63 \\
& y_{1} \quad=6.26 \mathrm{in}(15.88 \mathrm{~cm}) ; \\
& r^{2} \quad=11.1 \mathrm{in}^{2}\left(71.61 \mathrm{~cm}^{2}\right) ; \\
& c \quad=0.994 \text { in }(2.52 \mathrm{~cm}) ; \\
& R \quad=21.02 \text { in }(53.39 \mathrm{~cm}), \text { the pitch radius of the thread; } \\
& \mu \quad=0.3 \text { (Poisson's ratio); } \\
& k \quad=3.7, \text { the stress concentration factor; (5) } \\
& t \quad=12.19 \text { in (29.51 cm). }
\end{aligned}
$$

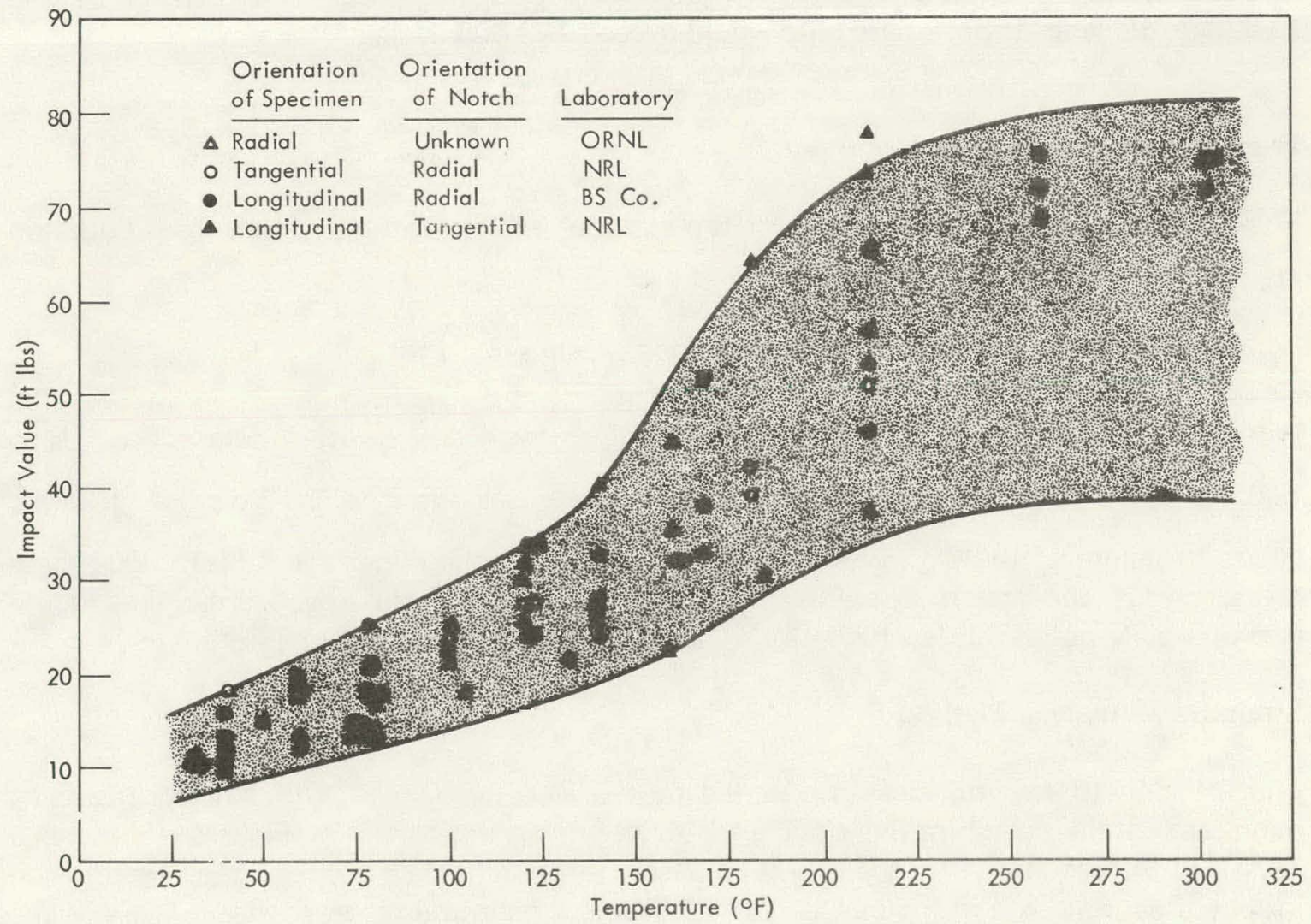

Figure 12. TRANSITION TEMPERATURE CURVE (CHARPY V-NOTCH) FROM POST-RUPTURED VESSEL SPECIMENS. 
Applying Equation 1a to the twin vessel gives:

$$
\begin{gathered}
\sigma_{z}=\frac{P}{A}\left(1+\frac{K_{m} Y_{1}}{r^{2}}\right), \text { or } \\
\sigma_{z}=36,800 \text { psi }(253.7 \mathrm{MPa}) .
\end{gathered}
$$

The stress range (longitudinal) at the first thread is:

$$
\begin{aligned}
S_{L}- & k(36,800)=3.7(36,800)-136,160 \mathrm{psi}(939 \mathrm{MPa}) \text { at the } 30,000-\mathrm{psi} \\
& (207-\mathrm{MPa}) \text { operating pressure, or } \\
S_{Z}= & \frac{22,500}{30,000}(136,200)=102,100 \mathrm{psi}(703.9 \mathrm{MPa}) \text { at the 22,500-psi (155.1-MPa) } \\
\text { operating pressure: } & \frac{102,150}{2}=51,075 \mathrm{psi}(352.1 \mathrm{MPa}) .
\end{aligned}
$$

Life at the 22,500-psi (155.1-MPa) operating pressure, with a 30-in (0.76-m) ID, is estimated at 5000 cycles, $(6)$ while at 15,000-psi (103.4-MPa) operating pressure, and with a 27.5-in (0.698-m)-ID liner, the estimated life would exceed 190,000 cycles.

\section{Fracture Niechanics Method}

The fracture toughness value, $\mathrm{K}_{\mathrm{I}^{\prime}}$ for the material of the ruptured vessel, from Equation $4 b$, was found to be:

$$
\mathrm{K}_{\mathrm{C}}=65,057 \mathrm{psi} \sqrt{\mathrm{in}}(71.5 \mathrm{MPa} \sqrt{\mathrm{m}})
$$

With the respective twin vessel criteria, the values for a and da were determined. Using Equations 4 and 5, the $\frac{d a}{d N}$ fatigue crack growth rate was obtained and gave over 190,000 cycles to failure of the twin vessel operating with the cooling liner and at a 15,000-psi gas pressure. But, the presenll operating temperature of $30^{\circ} \mathrm{C}$ at the lower thread area would give Charpy $V$-notch values which would indicate only 40,000 cycles to failure.

\section{Strain-Gage Analysis Method}

The 0.156 -in $(3.96 \mathrm{~mm}$ ) clearance at the root of the thread was sufficient for installing miniature strain gages in the original installation, as illustrated in Figures 13 through 18. $(1,12)$ Subsequently, in the modified vessel (a gas autoclave), strain gages were again installed, as indicated in Figures 19 and 20. Table 2 gives the recorded strain levels in the original tests; ${ }^{(12)}$ Table 3 lists the significant strain levels in the test of the modified vessel about ten years later. (13) 
Table 2

RECOFIDED STRAIN LEVELS ON THE THIRTY-INCH PRESSURE VESSEL (All Readings are in Microinches per Inch)

\begin{tabular}{|c|c|c|c|c|c|c|c|c|c|c|c|c|c|c|c|}
\hline \multirow{2}{*}{$\begin{array}{c}\text { Gage } \\
\text { Number }\end{array}$} & \multicolumn{14}{|c|}{ Pressure Level (psi)(1) } & \multirow{2}{*}{$\begin{array}{l}\text { Maximum } \\
\text { Corrected }\end{array}$} \\
\hline & Zero & 5,000 & 10,000 & Zero & 5,000 & 10,000 & 12,000 & 14,000 & 16,000 & 18,000 & 20,000 & 21,000 & 22,500 & Zero & \\
\hline 1 & 0 & 220 & 480 & 20 & 250 & 470 & 580 & 680 & 760 & 860 & 950 & 1000 & 1060 & -10 & 1250 \\
\hline 2 & 0 & 10 & 20 & 30 & -20 & 20 & 30 & 30 & 40 & 50 & 50 & 40 & 40 & -10 & 47 \\
\hline 3 & 0 & 920 & 1490 & 10 & 860 & 1500 & 1740 & 2020 & 2190 & 2430 & 2660 & 2770 & 2940 & -30 & 3470 \\
\hline 4 & 0 & 0 & 20 & 20 & -20 & 10 & 30 & 30 & $\cdot 40$ & 40 & 40 & 50 & 40 & -10 & 47 \\
\hline 5 & 0 & 510 & 1080 & 10 & 530 & 1070 & 1320 & 1600 & 1780 & 2010 & 2260 & 2370 & 2540 & 0 & 2995 \\
\hline 6 & 0 & 10 & 30 & 20 & 0 & 30 & 40 & 50 & 60 & 50 & 60 & 60 & 60 & -10 & 70 \\
\hline 7 & 0 & 560 & 1130 & 10 & 590 & 1130 & 1400 & 1710 & 1870 & 2110 & 2380 & 2500 & 2670 & -10 & 3150 \\
\hline 8 & 0 & 60 & 90 & 70 & 0 & 80 & 90 & 100 & 100 & 110 & 110 & 110 & 110 & 0 & 130 \\
\hline 9 & 0 & 960 & 1400 & -10 & 990 & 1400 & 1590 & 1760 & 1880 & 2020 & 2170 & 2240 & 2340 & -20 & 2760 \\
\hline 10 & 0 & -20 & 10 & -10 & -10 & 20 & 10 & 20 & 30 & 40 & 40 & 40 & 40 & 0 & 47 \\
\hline 11 & 0 & -25 & 60 & 0 & -120 & 60 & 170 & 310 & 410 & 530 & 660 & 720 & $820^{\circ}$ & 0 & 970 \\
\hline 12 & 0 & -10 & 30 & -10 & 10 & 40 & 40 & 50 & 50 & 60 & 60 & 60 & 70 & 0 & 83 \\
\hline 13 & 0 & 580 & 840 & -10 & $62 \mathrm{C}$ & 860 & 960 & 1070 & 1150 & 1250 & 1350 & 1400 & 1470 & 0 & 1735 \\
\hline 14 & 0 & -10 & 20 & -10 & $1 C$ & 40 & 40 & 50 & 50 & 60 & 60 & 60 & 70 & 0 & 83 \\
\hline 15 & 0 & -510 & -480 & -10 & 510 & 530 & 560 & 610 & 630 & 660 & 700 & 710 & 740 & -5 & 875 \\
\hline 16 & 0 & -40 & 20 & -10 & $2 C$ & 30 & 30 & 40 & 40 & 50 & 50 & 50 & 60 & 0 & 70 \\
\hline 17 & 0 & 450 & 790 & 0 & $47 C$ & 790 & 910 & 1050 & 1130 & 1250 & 1380 & 1430 & 1500 & -10 & 1770 \\
\hline 18 & 0 & 20 & 50 & 0 & $2 G$ & 40 & 50 & 50 & 50 & 60 & 70 & 70 & 70 & -10 & 83 \\
\hline 19 & 0 & 340 & 600 & 0 & $35 \mathrm{C}$ & 600 & 710 & 830 & 900 & 1000 & 1100 & 1135 & 1190 & -10 & 1400 \\
\hline $20^{\circ}$ & 0 & 0 & 30 & 0 & G & 30 & 30 & 40 & 40 & 50 & 50 & 55 & 50 & -10 & 60 \\
\hline
\end{tabular}

(1) All data from Long and Russ. (12) 
Table 3

RECORDED STRAIN-LEVEL COMPARISONS

[At the 15,000-psi (103.4-MPa) Operating

Pressure; From Chapman, et al $(13)$ ]

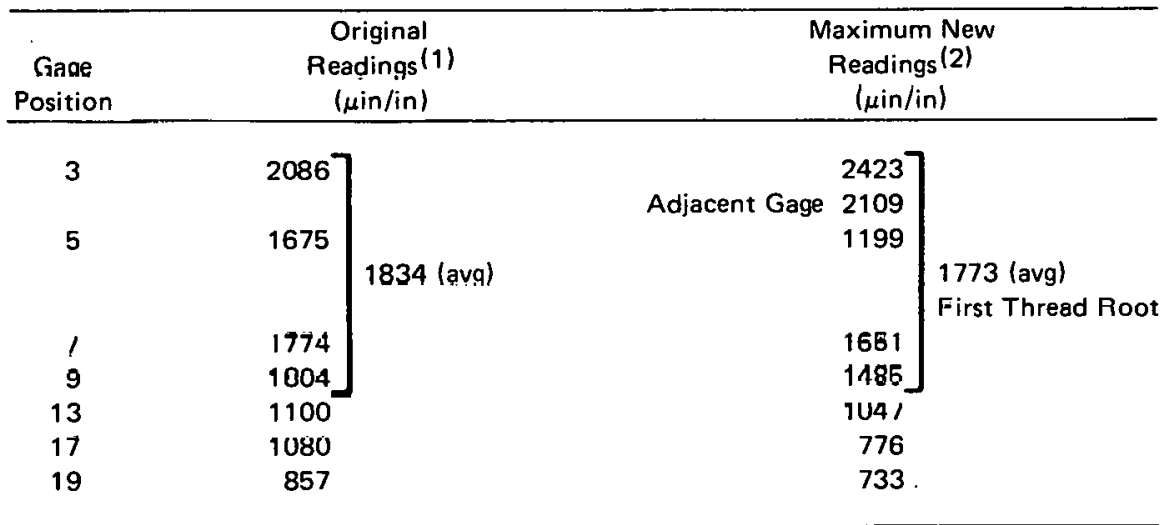

(1) Extrapolated with comparable 10.

(2) After modification to an autoclave.

The original strain-gage readings were taken at pressures up to 22,500 psi $(155.1 \mathrm{MPa}$ ) and with an ID of 30 in $(0.762 \mathrm{~m}$ ). Readings from the longitudinally installed gages (Gages 3, 5, 7 , and 9$)^{(c)}$ in the first thread root were averaged, giving a value of 3094 microinches per inch at 22,500 psi (155.1 MPa). The maximum range of stress was computed $(1)$ using the method of Singer: (14)

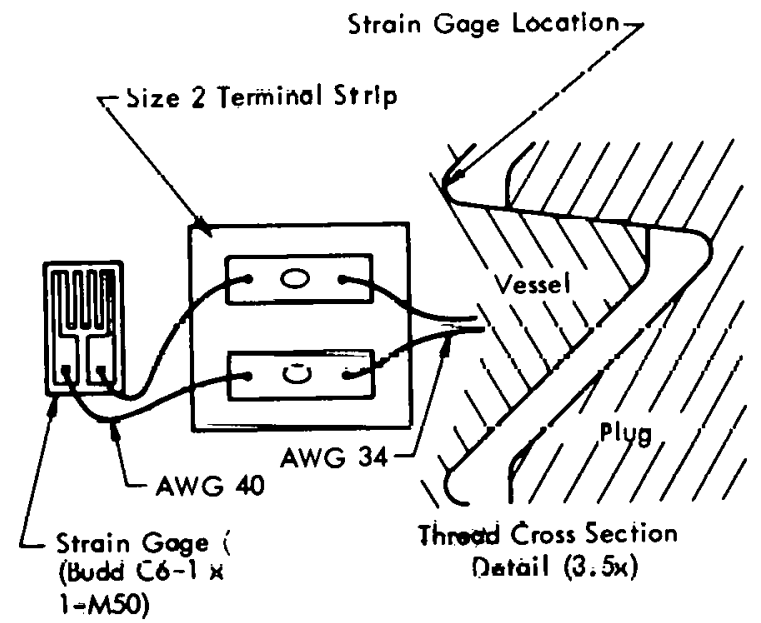

Figure 13. TYPICAL THREAD-ROOT INSTALLATION.

(c) The lower closure plug lacked full engagement by about one-sixth turn; therefore, Gage 1 was not under full load and its reading was voided. 


$$
\text { Maximum longitudinal stress }=S_{y}=\frac{E}{1-\mu^{2}}\left(e_{y}+\mu e_{x}\right)
$$

So:

$$
\begin{aligned}
& S_{y}=\frac{30,000,000}{0.91}\left(3094 \times 10^{-6}\right), \text { or } \\
& S_{y}=101,900 \text { psi }(702.5 \mathrm{MPa})[\text { at a } 22,500 \text {-psi (155.1-MPa) pressure] }
\end{aligned}
$$

In Equation 11:

E represents the modulus of elasticity $\left[30 \times 10^{6}\right.$ psi $\left.(206,841 \mathrm{MPa})\right]$,

$\mu \quad$ Poisson's ratio (0.3),

$e_{y}$ the longitudinal strain, and

$e_{x}$ the tangential strain (considered negligible).

$\mathrm{S}_{\mathrm{y}}$ is equivalent to $\mathrm{S}_{z}$.

The value of $S_{y}$ obtained $[101,900$ psi (702.6 MPa)], compares well with the 102,100-psi (703.96-MPa) stress range calculated by the direct-plus bending stross method.

\section{DISCUSSION}

At the time of the initial installation of the miniature strain gages at the root of the threads of the lower closure of the twin isostat, no corrosion was observed in that vicinity. Subsequently, the twin vessel was modified to a gas autoclave ${ }^{(2)}$ by adding an aluminum water-cooled liner and necessary electrical feed throughs in the lower plug (see Figures 6 and 7). After operating the twin vessel as a gas autoclave for several years, the lower plug and upper closure thread insert were removed. Corrosion at the lower threads was observed, believed to be caused by moisture condensation (see Figure 19). The corrosion in the first three thread roots was removed with a small hand grinding wheel. The maximum depth of the

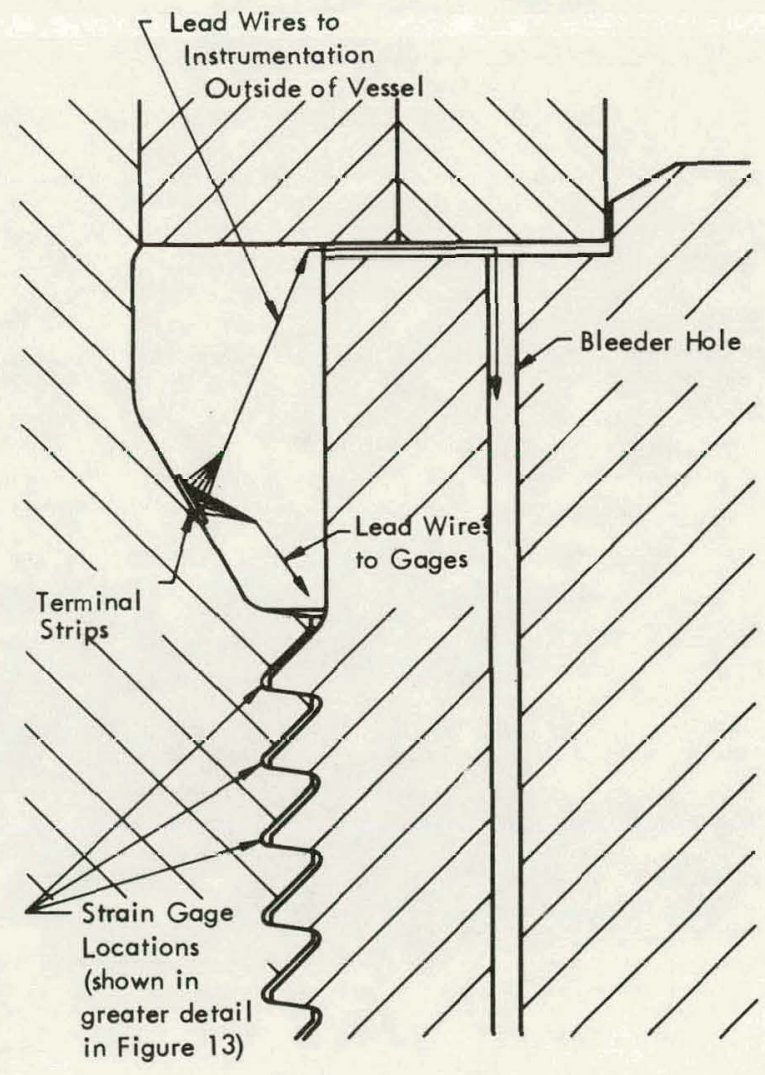

Figure 14. PLUG MATING TO THE END OF THE PRESSURE VESSEL. 


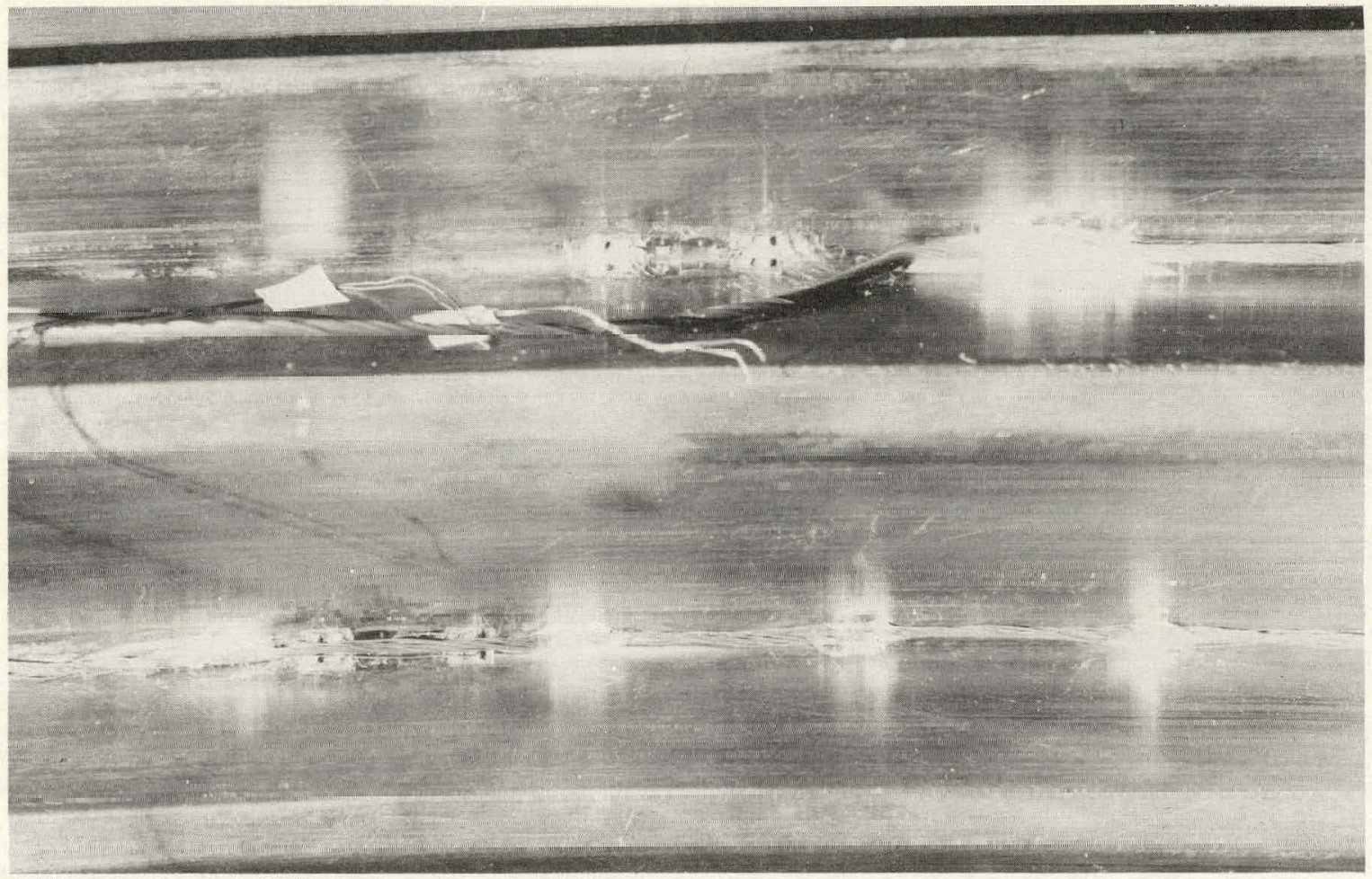

Figure 15. TYPICAL GAGE ATTACHMENT.

112411

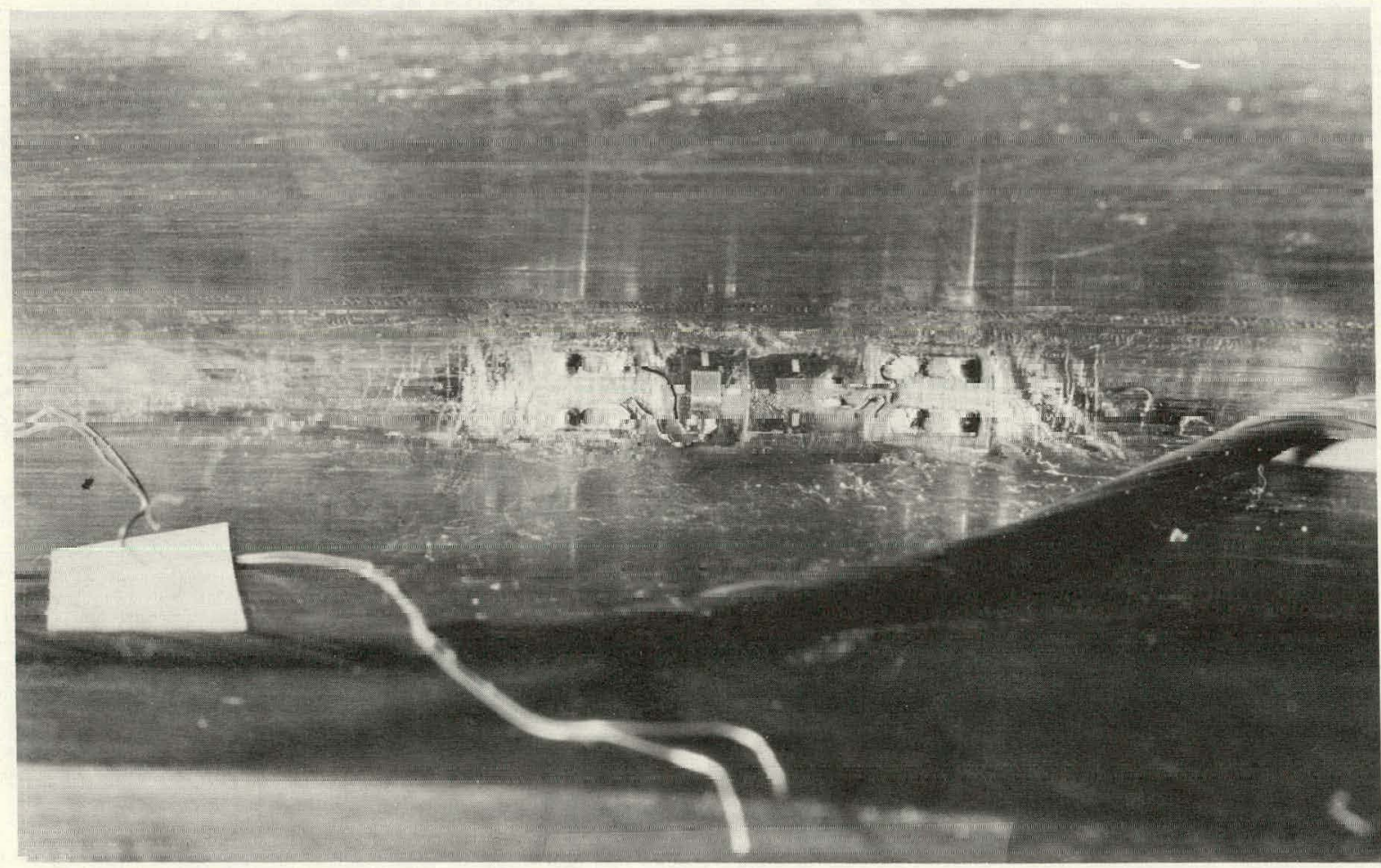

Figure 16. ENLARGED VIEW OF THE GAGE ATTACHMENT. 


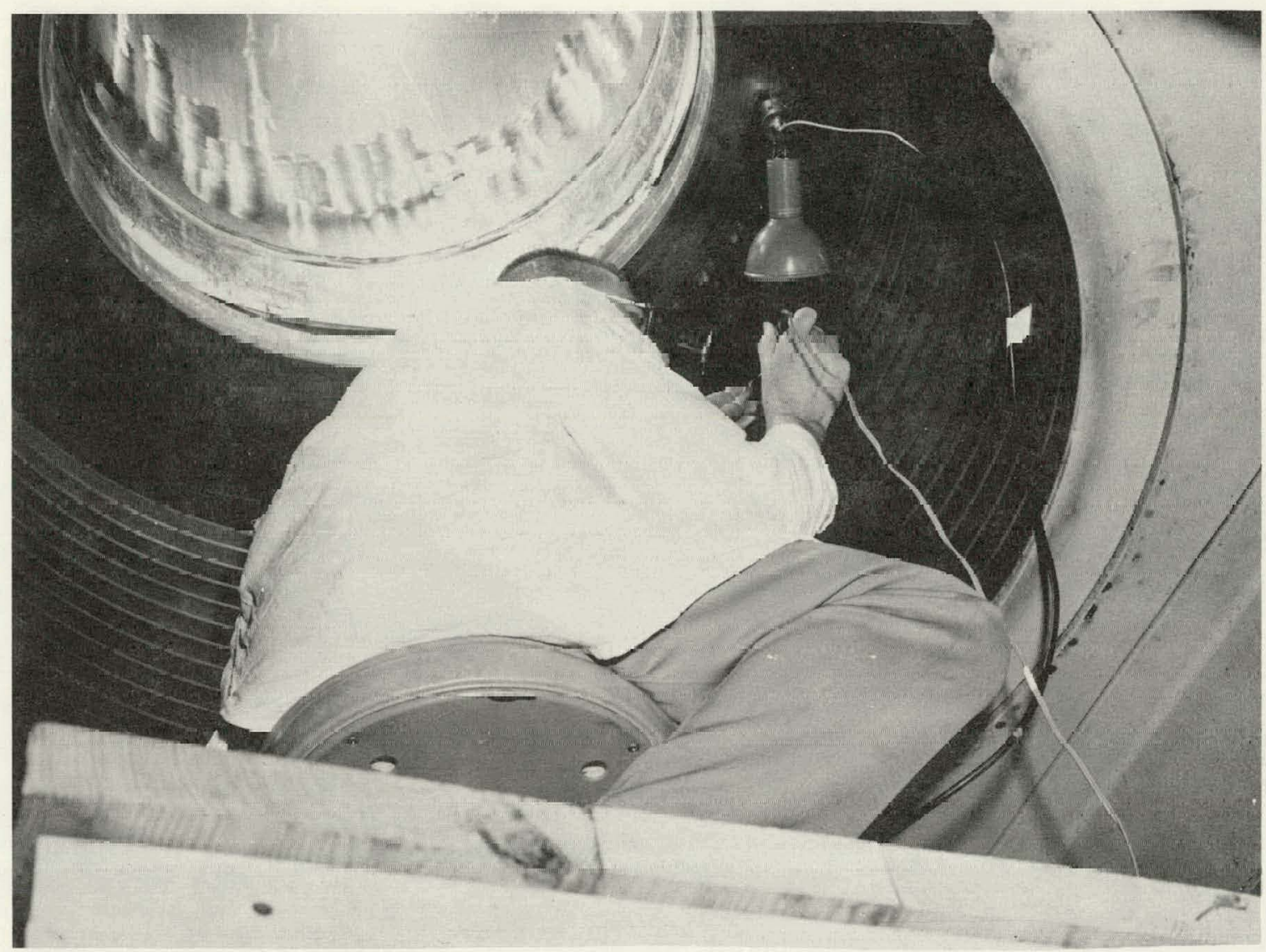

131732

Figure 17. INSTALLING A STRAIN GAGE.

pitting was 0.012 inch $(0.305 \mathrm{~mm})$ and averaged about 0.006 inch $(0.152 \mathrm{~mm})$, measured by the replicator method. (15)

Using the high-sensitivity ZL-30A fluorescent penetrant, a dye-penetrant inspection of the threads of the lower and upper closures was made of the twin vessel. An ultrasonic shear-wave inspection of the threads was also made (see Figure 21). Neither inspection detected any flaws or cracks, nor are Boussinesq shear cracks presumed to be present (note Figure 22).

New strain gages were installed(13) in the first three lower thread roots, attaching these as near the original location as possible. No significant change in the new strain readings was observed, compared to

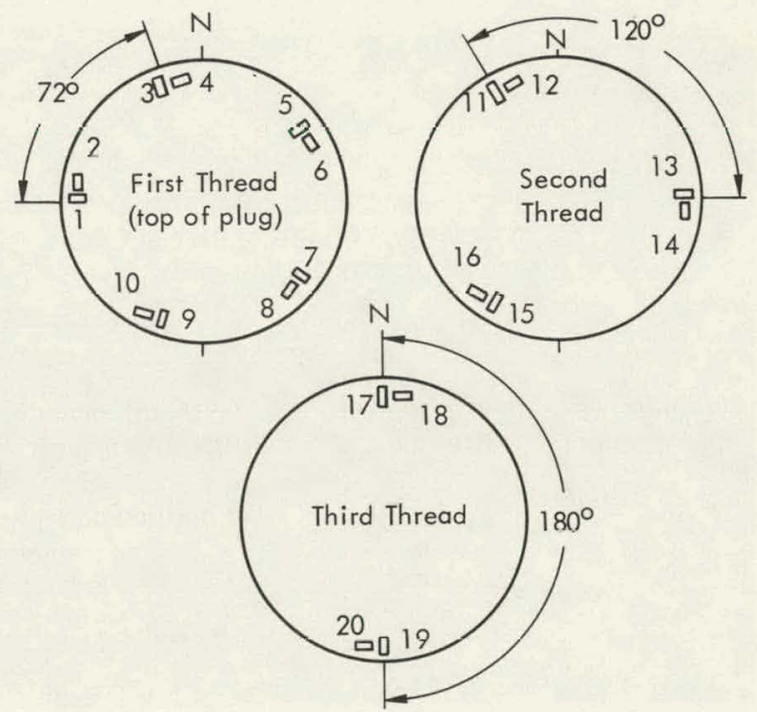

Figure 18. GAGE LOCATIONS IN THE THREE TEST THREADS. (Odd Numbers are Longitudinal Gages; Even Numbers are Circumferential Gages) 


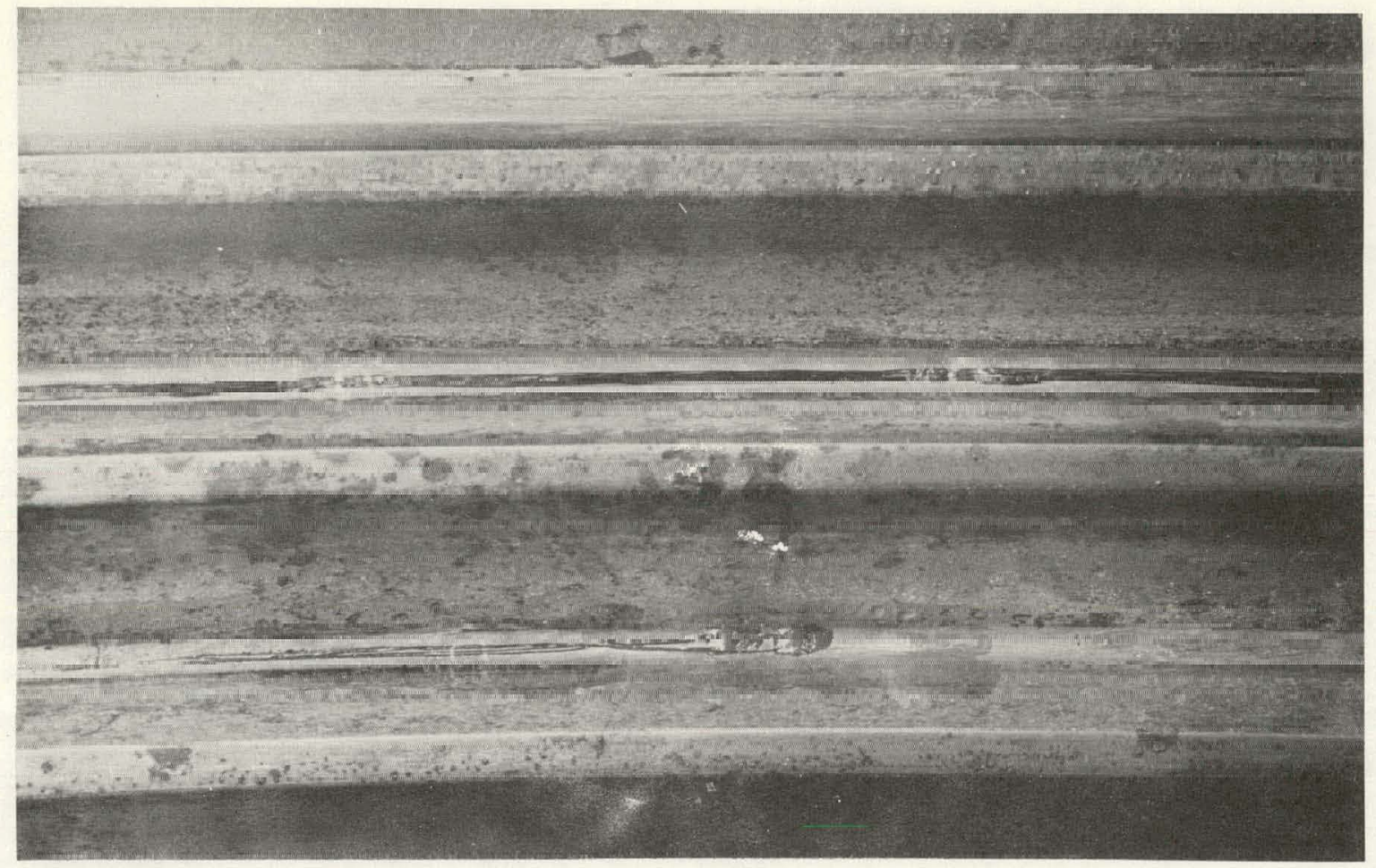

(a) Area 1.

155675

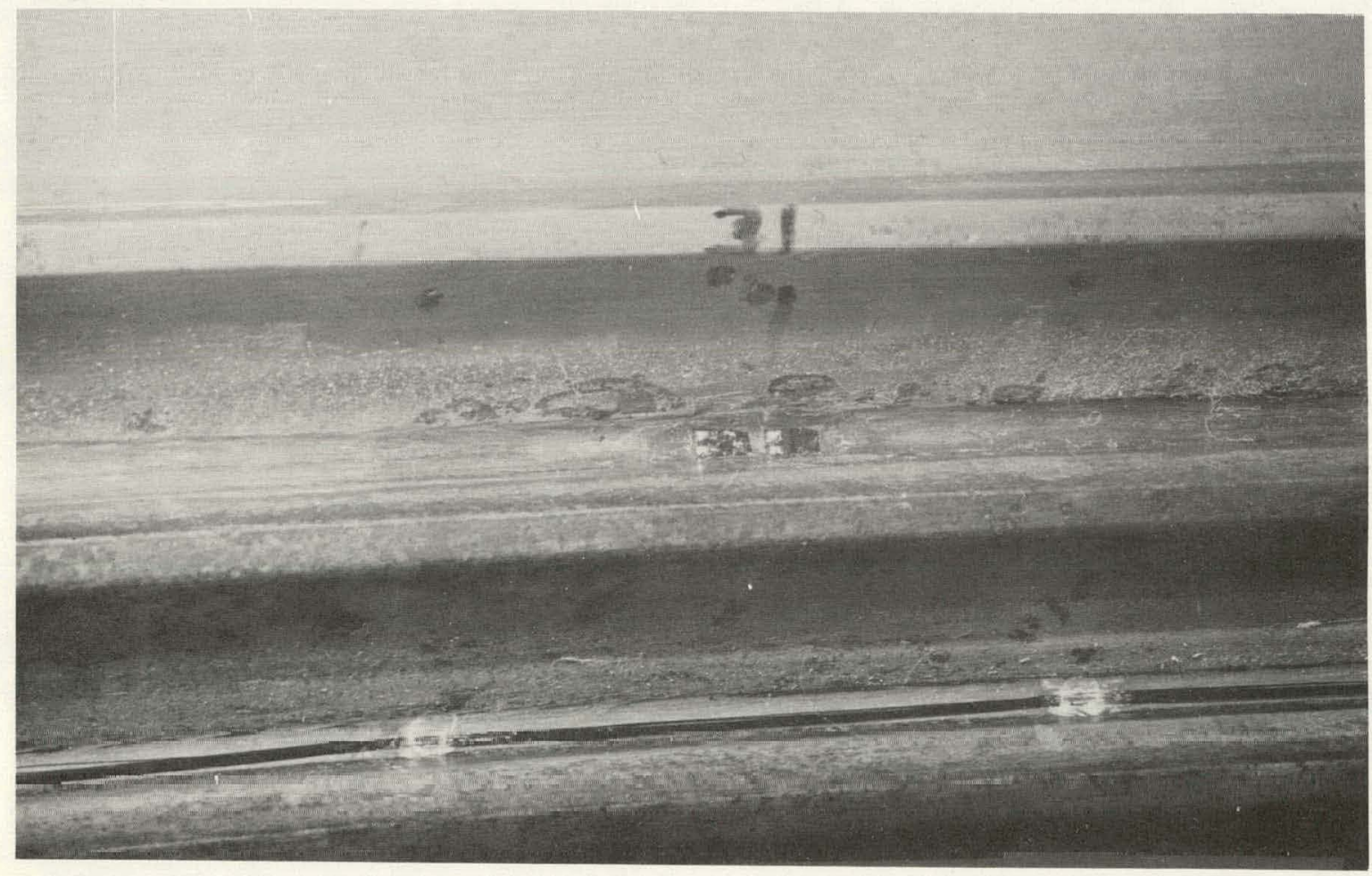

(b) Area 2

155674

Figure 19. TWO AREAS OF GAGES AND CORROSION. 


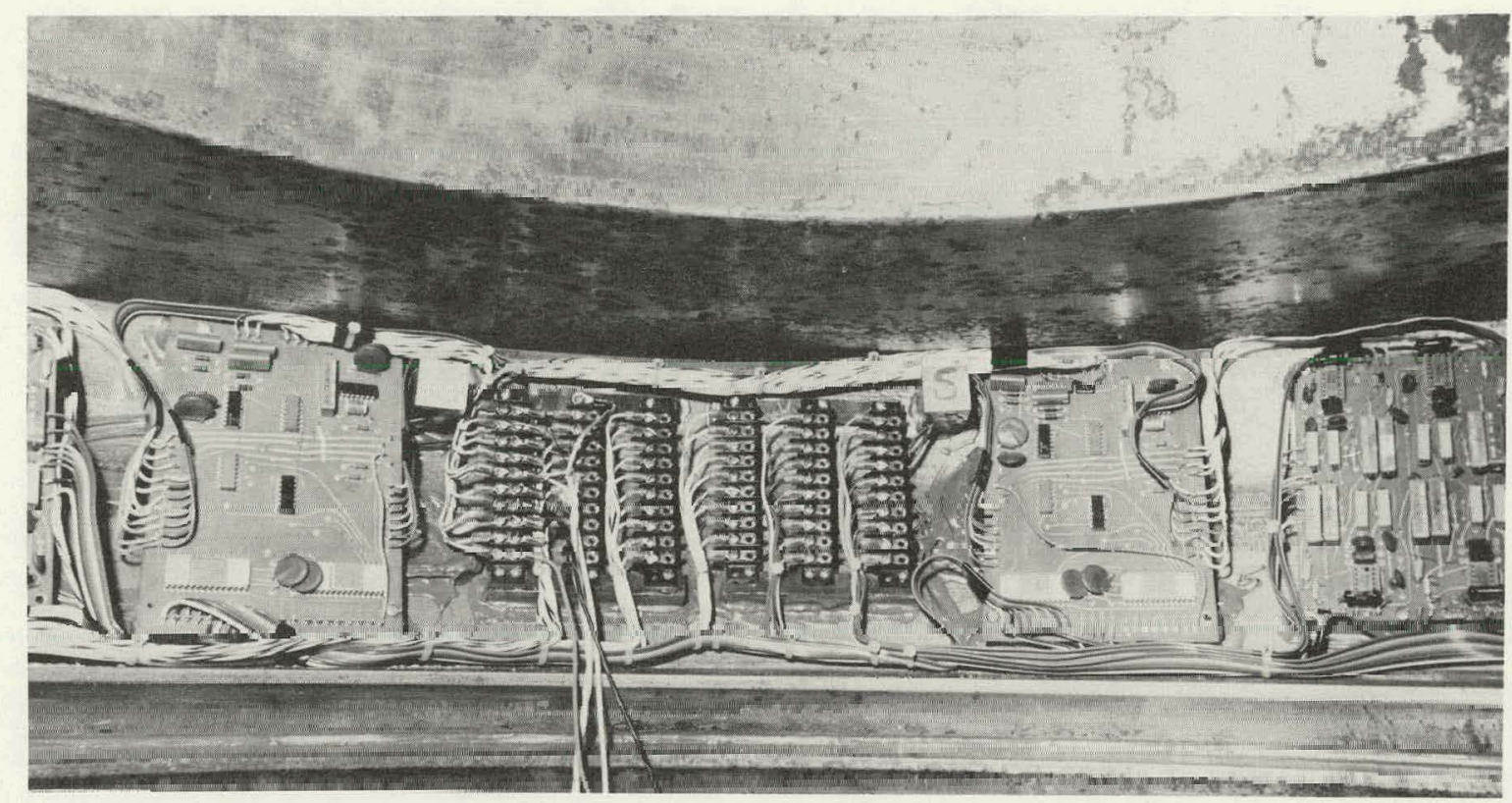

Figure 20. ELECTRONICS INSTALLATION.

156490

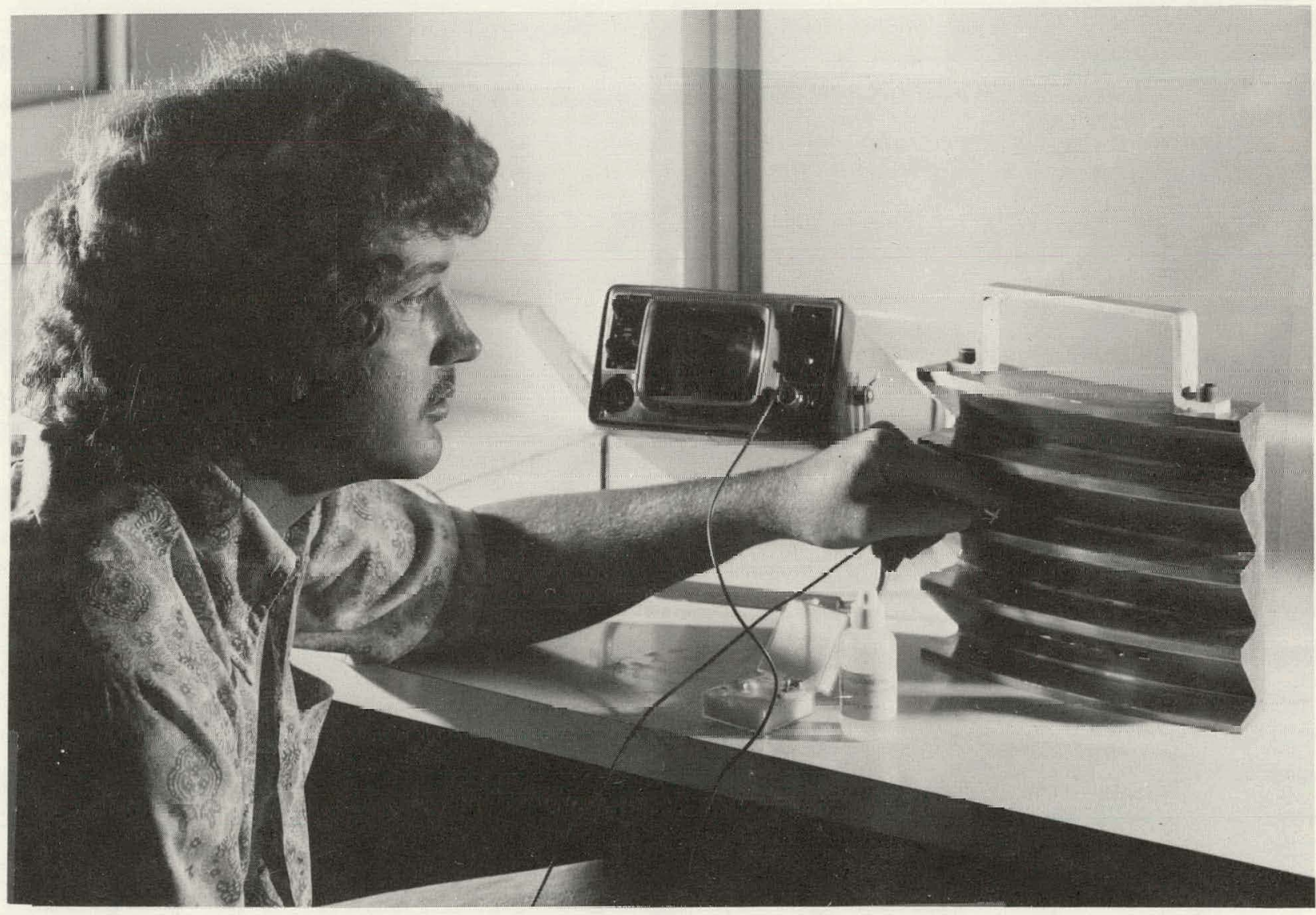

Figure 21. ULTRASONIC MODEL. 


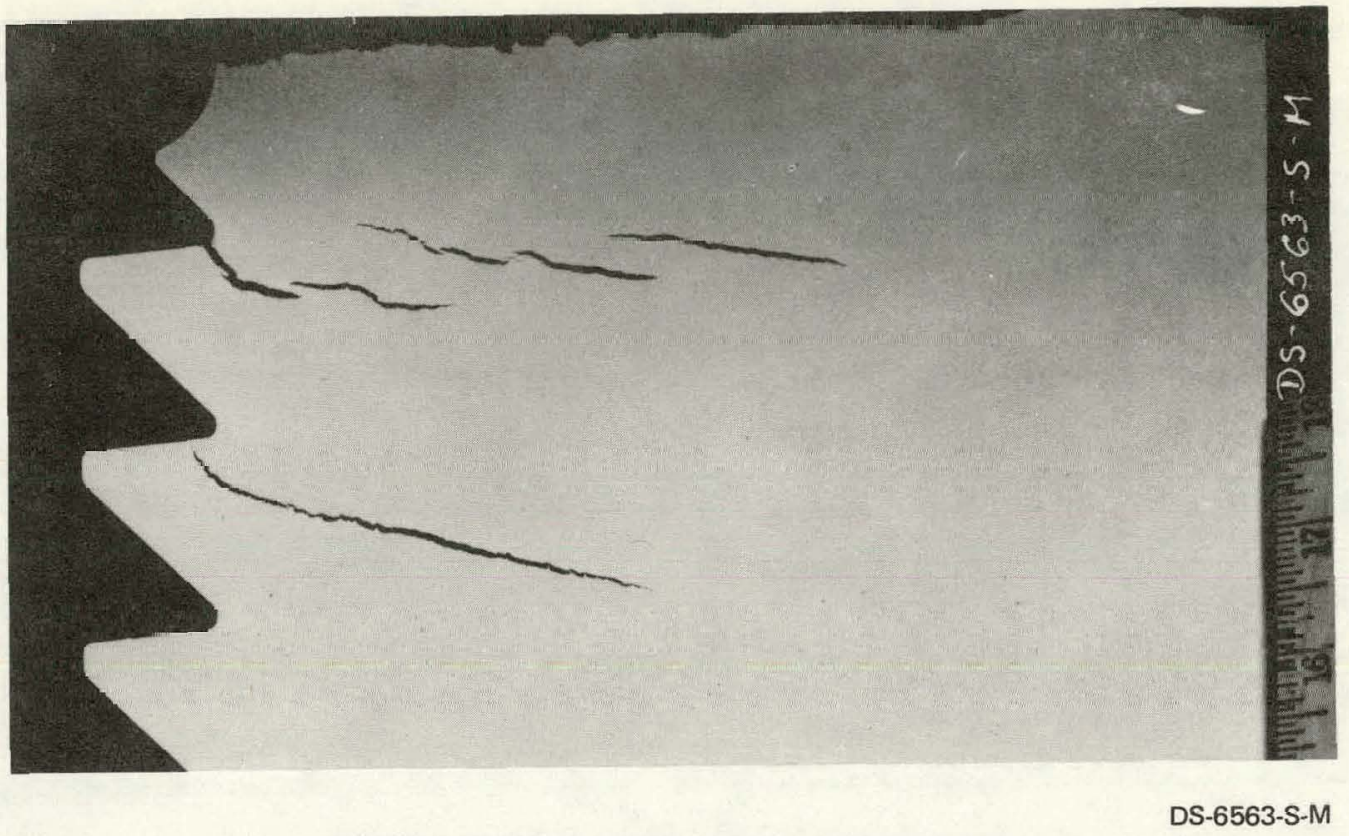

Figure 22. BOUSSINESQ SHEAR. (Actual Illustration)

the readings taken ten years earlier, compensating for the inside dimensional modification due to the installed cooling liner (see Table 3).

Thompson, (15) in an independent study, obtained a value of 1515 cycles to failure for the ruptured vessel, and up to 184,000 cycles for the twin isostat under the present operating parameters.

\section{CONCLUSIONS}

Post-failure-analysis and comparison studies of the two isostats reveal these significant observations:

1. Average strain-gage values obtained from the root of the first thread of the lower closure of the "twin" vessel gave a stress value of 101,900 psi (702.6 MPa) at a 22,500-psi (155.1-MPa) operating pressure. Calculations indicated an alternating stress range of $102,100 \mathrm{psi}$ (703.9 MPa) at the same location.

2. Using the same direct-plus-bending-stress calculating method for the ruptured vessel [for an operating pressure of 30,000 psi (207 MPa)] resulted in a 74,500-psi (513.6-MPa) alternating stress component $\left(\mathrm{S}_{\mathrm{a}}\right)$ for the first thread root-the point of failure. $(1)$ This value was interpreted as being equivalent to 1300 cycles of fatigue life from the ASME Section VIII, Division 2, Design Fatigue Curve ${ }^{(6)}$ (Figure 9).

3. Analyses of the two vessels, utilizing fracture mechanics and fatigue crack growth determinations, showed a calculated fatigue life for the ruptured vessel of 1362 - 1590 cycles, and over 190,000 cycles for the twin vessel at the present reduced operating parameters. But, the present operating temperature of $30^{\circ} \mathrm{C}$ at the lower thread area would give Charpy $V$-notch values which would indicate only 40,000 cycles to failure. 
4. The 45,000-psi (310.3-MPa) pressure test conducted by the manufacturer could have resulted in the following: (1) autofrettaging the highly strained area of the first thread root, as shown by the Bauschinger effect curve (Figure 23) with a possible compressive residual stress remaining which should extend the fatigue life; (2) possibly initiated the beginning of microscopic cracks which resulted in the Boussinesq shear-type flaws shown in Figure 22. Neither conclusion has been drawn.

5. The temperature of the vessel was approximately $17^{\circ} \mathrm{C}$ at the time of failure. The NDT of the steel in these vessels is $54^{\circ} \mathrm{C}$, but this information was not known prior to failure. The pressure vessels were constructed from nickel steel forgings (see Table 1).

6. After over ten years of operating the "twin" vessel, no evidence of flaws was detected either by ultrasonic-shear-wave inspection or high-sensitivity dyepenetrant inspection, (13) and no micro-

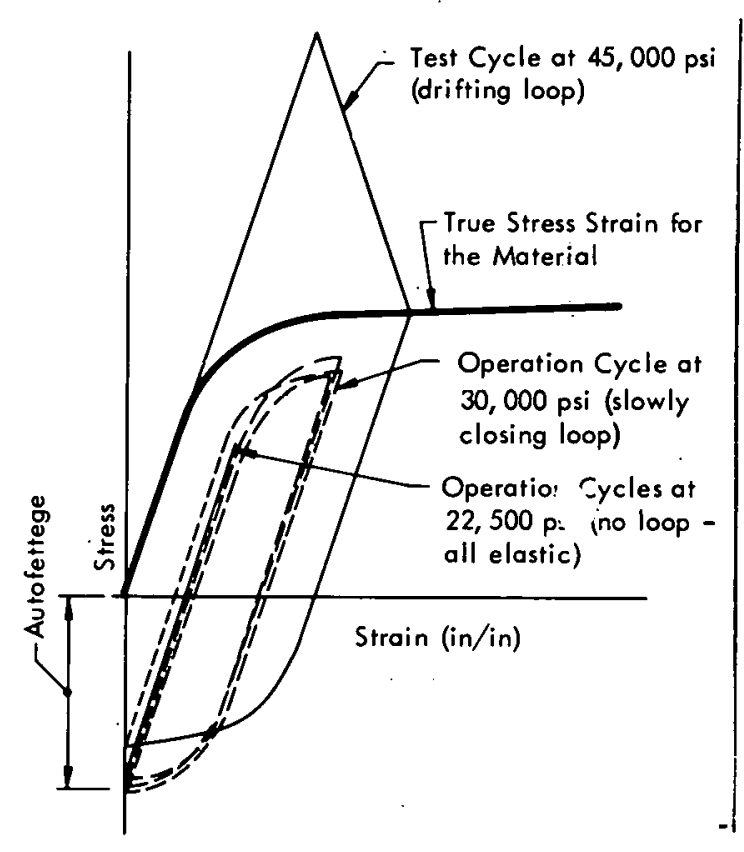

Figure 23. BAUSCHINGER EFFECT CURVE. (IIlustrative Only) scopic crackś are presumed to exist.

7. Strain=gäge readlings over a ten-year period showed no significant changes. (13) The root of the interrupted thread of the upper closure indicates stresses $\left(S_{a}\right)$ in the 39,000-psi (268.8-MPa) range at a 15,000-psi (103.4-MPa) operating pressure. These upper threads are normally near the NDT when the vessel is operating as an autoclave and the lower threads are at approximately $30^{\circ} \mathrm{C}$.

8. A strain-gaye analysis of the outside wall of the ruptured vessel was performed by the manufacturer during the hydro test. Figure 24 gives definite indication of bending stresses in the outer shell at the first thread area.

\section{RECOMMENDATIONS}

Fatigue life can be predicted for isostats with threaded closures under cyclic Inading. Several methods arc now available for calculating fatigue life. Fracture mechanics analysis is an acceptable and reliable method. This information should be utilized during the design of future isostats.

The designer should obtain material physical properties and fracture model data prior to design or construction. This information may be obtained from existing publications, manufacturers data, or actual laboratory tests. 


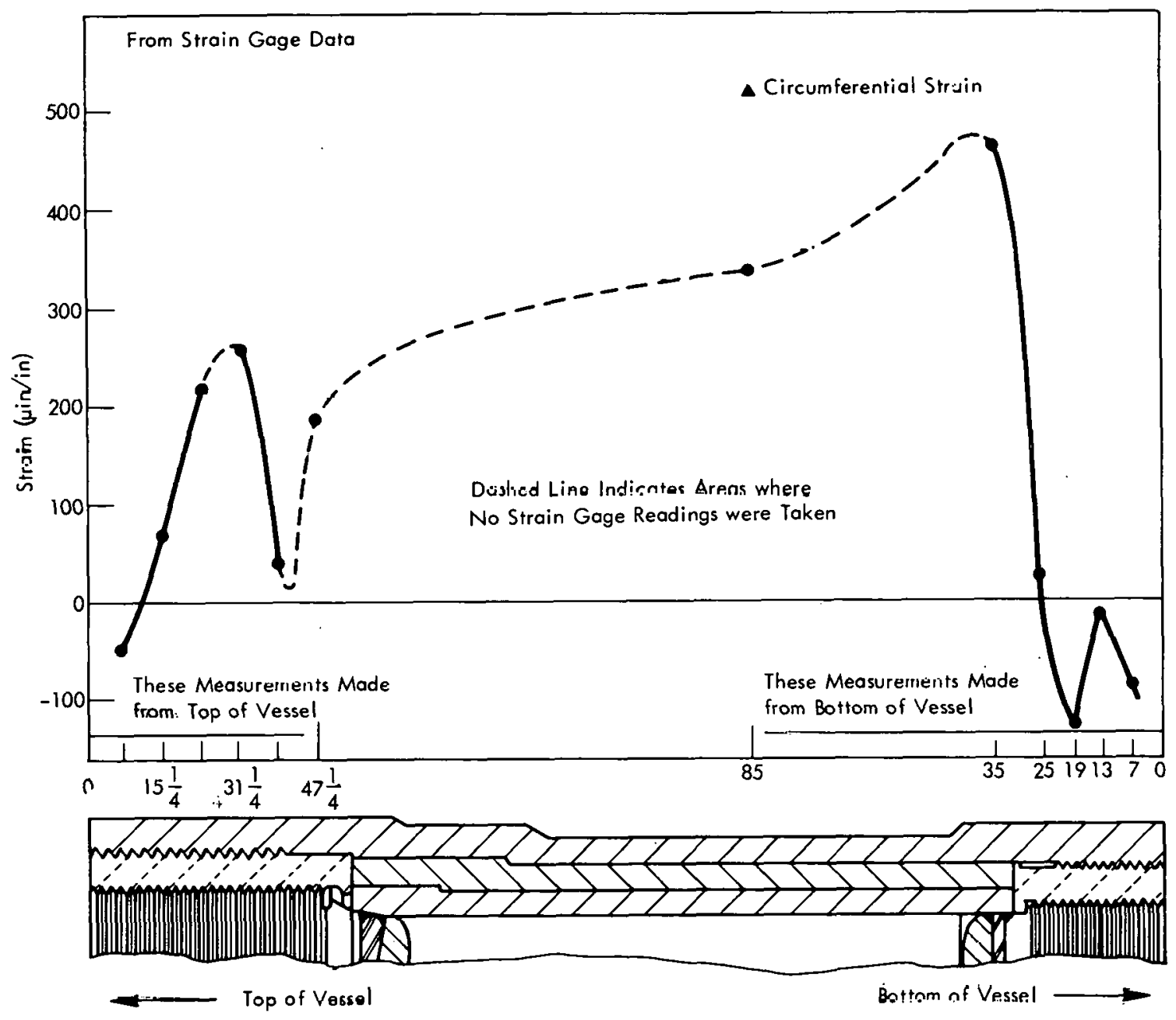

Figure 24. LONGITUDINAL STRAIN DISTRIBUTION OF THE 30"-10 PRESSURE VESSEL (VESSEL 1 AT THE 30,000-psi STRAIN GAGES ON THE OUTSIDE SURFACE OF THE VESSEL. (Measurements Taken by the Manufacturer During a Hydro Test)

All designs for high-pressure vessels for cyclic loading should be analyzed for fatigue life. For pressure vessels with threaded closures, the area of the threaded closure is a critical area and should be ànalyzed.

The present reduced operatiruy parameters of the twin isostat should be observed. 


\section{REFERENCES}

(1) Pohto, H. A.; Aspects of the Brittle Fracture Failure of a 30-inch-ID, 30,000-psi Isostat with Threaded Closure, Y-1758; Union Carbide Corporation-Nuclear Division, Oak Ridge Y-12 Plant, Oak Ridge, Tennessee; April 30, 1971.

(2) Pohto, H. A. and St. Onge, C. D.; "Mechanical Design Criteria and Analyses for Converting PV II to a Gas Autoclave", Compendium of Gas Autoclave Engineering Studies, Edited by C. E. Muzzall, Y-1478; Union Carbide Corporation-Nuclear Division, Oak Ridge Y-12 Plant, Oak Ridge, Tennessee; August 23, 1965.

(3) Timoshenko, S.; "Strength of Materials, Part II", Advanced Theory and Problems, Second Edition, p 32, et seq; D. Van Nostrand Company, Inc.

(4) Timoshenko, S. and Woinosky-Krieger, S.; Theory of Plates and Shel/s, Second Edition, pp 466 - 474; McGraw-Hill Book Company, Inc, New York, New York.

(5) Peterson, R. E.; Figure 33 of Stress Concentration Design Factors; John Wiley and Sons, Inc, New York, New York (1953).

(6) ASME Boiler and Pressure Vessel Code, Section VIII; Pressure Vessels-Division 2, Figure 5-110.1; American Society of Mechanical Engineers, United Engineering Center, New York, New York (1968).

(7) Wessel, E. T. and Mager, T. R.; "The Fracture Mechanics Approach to Reliability in Nuclear Pressure Vessels", The Technology of Pressure Retaining Steel Components, $\mathrm{p}$ 152, Edited by M. S. Wechsler; The Metallurgical Society of the American Institute of Mining, Metallurgical, and Petroleum Enyineers, Inc, New York, New York (1970).

(8) Barsom, J. M.; "Fatigue Behavior of Pressure-Vessel Steels", Welding Research Council, Bulletin 194; May 1974.

(9) Merkle, J. G.; A Review of Sume of the Existing Stress Intensity Factor Solutions for Part-Through Surface Cracks, ORNL-TM-3983, p 42; Union Carbide Corporation-Nuclear Division, Oak Ridge National Laboratory, Oak Ridge, Tennessee (1973).

(10) Paris, P. C. and Sih, G. C.; "Stress Analysis of Cracks", Fracture Toughness Testing and its Applications, 1964 Symposium, ASTM STP 381, p 69.

(11) Corten, H. T. and Sailors, R. H.; "Relationship Between Material Fracture Toughness Using Fracture Mechanics and Transition Temperature Tests", HSST Program Tech Report 15, p 9; August 1, 1971.

(12) Long, P. J. and Ross, W. D.; Strain Gage Test at the Threaded Closure on a Thirty-Inch Pressure Vessel, Y-1471: Union Carbide Corporation Nuclear Division, Oak Ridge Y-12 Plant, Oak Ridge, Tennessee; November 20, 1964. 
(13) Chapman, S. L., Kowalewski, J. A., and Olmstead, C. R.; Strain Monitor System for the Threaded Closure on a 30-Inch Pressure Vessel, Y-DL-453; Union Carbide Corporation-Nuclear Division, Oak Ridge Y-12 Plant, Oak Ridge, Tennessee (1974).

(14) Singer, F. L.; Strength of Materials, Second Edition, p 38; Harper and Row Publishers, New York, New York.

(15) Thompson, W. F.; Personal Communication; Union Carbide Corporation-Nuclear Division, Oak Ridge Y-12 Plant, Oak Ridge, Tennessee. 


\section{ACKNOWLEDGEMENTS}

For their contributions and assistance, the author wishes to thank the following Union Carbide Corporation-Nuclear Division personnel: H.W. Blake of the ORGDP, J. G. Merkle of the HNL, and S. L. Chapman, C. R. Olmstead, and F. W. Thompson of the Y-12 Plant. 


\section{APPENDIX}

\section{NOMENCLATURE}

A Area of the cross section of the shell subtended by one inch of thread length at the pitch radius (see Figure 8).

a

Crack length.

$\mathrm{a}_{\mathrm{C}} \quad$ Critical crack length.

b Inside radius of the pressure vessel.

e bepth of the lliread.

$\mathrm{C}_{\mathrm{V}} \quad$ Charpy impact value.

E Modulus of elasticity, in psi.

$e_{x} \quad$ Tangential strain.

ey Longitudinal strain.

$f\left(\frac{a}{t}\right)$. Tabulated stress factor, dimensionless. $(9)$

$g\left(\frac{a}{t}\right) \quad$ Tabulated average stress shape factor, dimensionless. $(9)$

$h\left(\frac{d}{t}\right) \quad$ Tabulated shape factor. (7)

I Moment of inertia of the shell of Section A (also equal to $A_{1}^{2}$ ).

$k$ Strees concentration factor.

$k\left(\frac{a}{\tau}\right) \quad$ Tabulated shape tactor. (7)

$K_{1} \quad$ Stress intensity factor.

$\mathrm{K}_{\mathrm{C}} \quad$ Critical stress intensity factor.

$\mathrm{K}_{\mathrm{O}} \quad$ Initial stress intensity factor.

$K_{m} \quad$ Portion of the total moment carried by the thread section of the shell. 


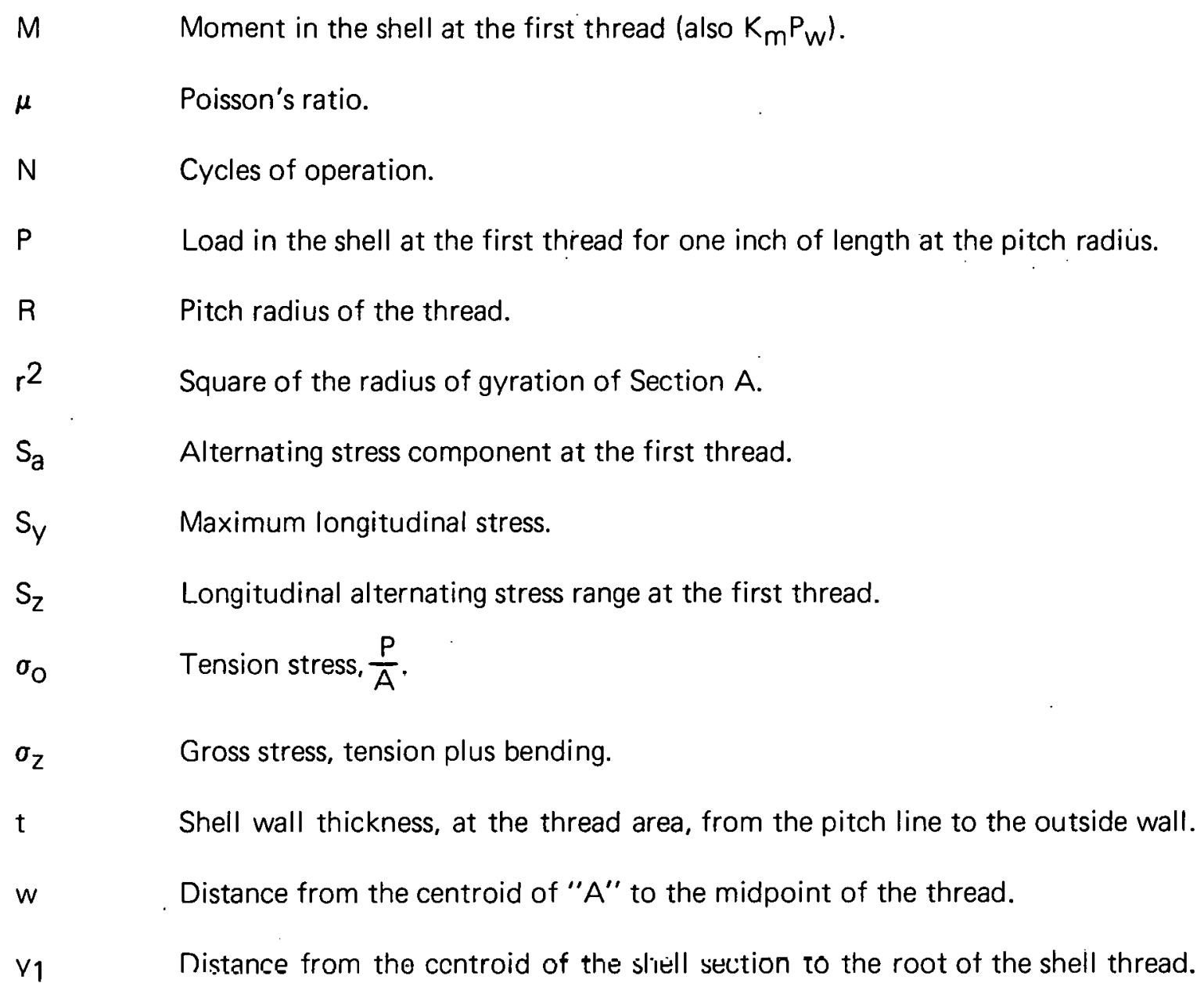




\section{Distribution}

Energy Research and Development Administration - Oak Ridge

Hickman, H. D.

Leed, R. E.

Zachry, D. S., Jr

Holifield National Laboratory

Merkle, J. G.

Oak Fidgc Gaseous Diffusinn Plant

Blake, H. W.

Stief, S. S.

Wilcox, W. J., Jr

\section{Oak Ridge Y-12 Plant}

Alvey, H. E.

Bernander, N. K.

Briscoe, O. W.

Burditt, R. B.

Burkhart, L. E.

Chapman, S. L.

Ellingson, R. $\cap$

Foulk, D. L.

Fraser, R. J.

Hudulleston, R. L.

Jackson, V. C.

Jones, F. W.

Kahl, K. G.

Keith, A.

Kite, H. T.

Lundir, M. I.

McLendon, J. D.

Mills, J. M., Jr

Oliphant, G.W.

Olmstead, C. R.

Phillips, L. R.

Pohto, H. A. (5)

Smith, R. D.

Stoner, H. H.
Tewes, W. E.

Thompson, W. F.

Valentine, C. K.

Weathersby, W. E.

Whitson, W. K.

Yaggi, W. J./Googin, J. M.

Y-12 Central Files (5)

$Y-12$ Central Files (master copy)

$Y-12$ Central Files (route copy)

$Y=12$ Central Files (Y-12RC)

Zerby, C. D.

Paducah Gaseous Diffusion Plant

Levin, R. W.

In addition, this report is distributed in accordance with the category UC-38, Engineering and Equipment, as given in the USERDA Standard Distribution Lists for Unclassified Scientific and Technical Reports, TID-4500. 